\title{
Direct and semi-direct aerosol radiative effect on the Mediterranean climate variability using a coupled regional climate system model
}

\author{
Pierre Nabat $\cdot$ Samuel Somot $\cdot$ Marc Mallet • \\ Florence Sevault $\cdot$ Marc Chiacchio $\cdot$ \\ Martin Wild
}

Received: 27 September 2013/Accepted: 28 May 2014/Published online: 12 June 2014

(C) The Author(s) 2014. This article is published with open access at Springerlink.com

\begin{abstract}
A fully coupled regional climate system model (CNRM-RCSM4) has been used over the Mediterranean region to investigate the direct and semi-direct effects of aerosols, but also their role in the radiation-atmosphereocean interactions through multi-annual ensemble simulations (2003-2009) with and without aerosols and oceanatmosphere coupling. Aerosols have been taken into account in CNRM-RCSM4 through realistic interannual monthly AOD climatologies. An evaluation of the model has been achieved, against various observations for meteorological parameters, and has shown the ability of CNRM-RCSM4 to reproduce the main patterns of the Mediterranean climate despite some biases in sea surface temperature (SST), radiation and cloud cover. The results concerning the aerosol radiative effects show a negative surface forcing on average because of the absorption and scattering of the incident radiation. The SW surface direct effect is on average $-20.9 \mathrm{Wm}^{-2}$ over the Mediterranean Sea, $-14.7 \mathrm{Wm}^{-2}$ over Europe and $-19.7 \mathrm{Wm}^{-2}$ over
\end{abstract}

P. Nabat $(\bowtie) \cdot$ S. Somot $\cdot$ F. Sevault

Météo-France UMR3589, CNRS - CNRM-GAME, Centre

National de Recherches Météorologiques, 42 Avenue Gaspard

Coriolis, 31057 Toulouse, France

e-mail: pierre.nabat@meteo.fr

\section{Mallet}

Laboratoire d'Aérologie, UMR5560, 16 Avenue Edouard Belin, Toulouse, France

M. Chiacchio

The Abdus Salam International Centre for Theoretical Physics, Strada Costiera 11, 34100 Trieste, Italy

M. Wild

Institute for Atmospheric and Climate Science, ETH Zurich,

Univ Str 16, Zurich, Switzerland northern Africa. The LW surface direct effect is weaker as only dust aerosols contribute $\left(+4.8 \mathrm{Wm}^{-2}\right.$ over northern Africa). This direct effect is partly counterbalanced by a positive semi-direct radiative effect over the Mediterranean Sea $\left(+5.7 \mathrm{Wm}^{-2}\right.$ on average) and Europe $\left(+5.0 \mathrm{Wm}^{-2}\right)$ due to changes in cloud cover and atmospheric circulation. The total aerosol effect is consequently negative at the surface and responsible for a decrease in land (on average $-0.4{ }^{\circ} \mathrm{C}$ over Europe, and $-0.5{ }^{\circ} \mathrm{C}$ over northern Africa) and sea surface temperature (on average $-0.5{ }^{\circ} \mathrm{C}$ for the Mediterranean SST). In addition, the latent heat loss is shown to be weaker $\left(-11.0 \mathrm{Wm}^{-2}\right)$ in the presence of aerosols, resulting in a decrease in specific humidity in the lower troposphere, and a reduction in cloud cover and precipitation. Simulations also indicate that dust aerosols warm the troposphere by absorbing solar radiation, and prevent radiation from reaching the surface, thus stabilizing the troposphere. The comparison with the model response in atmosphere-only simulations shows that these feedbacks are attenuated if SST cannot be modified by aerosols, highlighting the importance of using coupled regional models over the Mediterranean. Oceanic convection is also strengthened by aerosols, which tends to reinforce the Mediterranean thermohaline circulation. In parallel, two case studies are presented to illustrate positive feedbacks between dust aerosols and regional climate. First, the eastern Mediterranean was subject to high dust aerosol loads in June 2007 which reduce land and sea surface temperature, as well as air-sea humidity fluxes. Because of northern wind over the eastern Mediterranean, drier and cooler air has been consequently advected from the sea to the African continent, reinforcing the direct dust effect over land. On the contrary, during the western European heat wave in June 2006, dust aerosols have contributed to reinforcing an important ridge responsible for dry and 
warm air advection over western Europe, and thus to increasing lower troposphere $\left(+0.8^{\circ} \mathrm{C}\right)$ and surface temperature $\left(+0.5^{\circ} \mathrm{C}\right)$, namely about $15 \%$ of this heat wave.

Keywords Aerosol - Radiation - Mediterranean · Regional climate · Dust

\section{Introduction}

Atmospheric aerosols play a significant role in the climate system because of their influence on the radiative budget of the Earth (e.g. Kaufman et al. 2002). Their microphysical and optical properties drive their interactions with shortwave (SW) and longwave (LW) radiation, with ensuing impacts on climate. The direct effect consists in the absorption and scattering of the incident radiation (e.g. Mitchell 1971; Coakley et al. 1983). This absorption can also heat the atmosphere and thus affect its dynamics and the evaporation of clouds (semi-direct effect, Hansen et al. 1997; Allen and Sherwood 2010). Due to their role as condensation nuclei, aerosols can also modify the amounts and the microphysical and radiative properties of clouds (indirect effect, e.g. Twomey 1977; Albrecht 1989; Lohmann and Feichter 2005). The quantification of all these effects on the radiative budget still shows large uncertainties (IPCC 2007). Besides, their high variability in space and time poses another difficulty to simulate their climatic effects. Studies at the regional scale form a possibility to better assess their impact on climate (e.g. Giorgi et al. 2002, 2003).

The Mediterranean region is indeed one of the regions which have the highest aerosol loads owing to air masses carrying numerous and various aerosol types (Lelieveld et al. 2002). These anthropogenic and natural aerosols, such as industrial and urban aerosols from European and North African towns, forest fires, biomass burning from eastern Europe, dust aerosols from Africa and marine particles, lead to strong effects on the regional radiative budget, climate and ecosystems of the Mediterranean (Rodá et al. 1993; Rosenfeld et al. 2001; Bergamo et al. 2008; Guieu et al. 2010). This diversity results in a large variety in physico-chemical and optical aerosol properties over the basin (Basart et al. 2009).

Numerous studies have used in-situ measurements and radiative transfer models to quantify the direct effect of different aerosol types over the Mediterranean basin: notably dust aerosols (Meloni et al. 2003, 2004), biomass burning aerosols (Formenti et al. 2002), anthropogenic aerosols (Markowicz et al. 2002) and pollution particles (Roger et al. 2006; Mallet et al. 2006). Up to now, aerosol radiative and climatic effects have essentially been studied using numerical simulations covering short-time periods.
Zanis (2009) has for instance studied the direct effect of anthropogenic aerosols over southeastern Europe during summer 2000 with the regional climate model (RCM) RegCM-3, showing a change of the pattern anomalies of this summer between simulations with and without aerosols. Santese et al. (2010) have studied the direct and semidirect effects of dust outbreaks over the Mediterranean in July 2003 using the same model. The regional chemistryclimate model COSMO-ART (Vogel et al. 2009) has also been used in several aerosol-climate studies over Europe including the indirect effect (Vogel et al. 2009; Bangert et al. 2011), but only for simulations of several days. Similar simulations of several days have also been carried out to investigate absorbing aerosols in the COSMOMUSCAT version (Meier et al. 2012). Fewer studies have carried out multi-annual simulations including aerosols in RCMs over the Euro-Mediterranean region. A 1-year simulation by Ekman and Rodhe (2003) using the RCA2 model has focused on the indirect effect of anthropogenic aerosols over Europe. Spyrou et al. (2013) have shown the profound effect of dust aerosols on the Mediterranean budget using a radiative transfer scheme in the dust SKYRON model for a 6-year simulation. The effect of anthropogenic aerosols over Europe has been studied in Zanis et al. (2012) using a RegCM3 simulation (1996-2007). Nabat et al. (2012) have carried out a 10-year simulation with RegCM4 incorporating an interactive aerosol scheme. The COSMO-CLM version has been used to study the dimming-brightening phenomenon over Europe for the period 1958-2001 (Zubler et al. 2011), but the role of ocean-atmosphere coupling is not treated in these simulations.

The Mediterranean region is characterized by mild wet winters and warm to hot, dry summers (Lionello et al. 2006), and is influenced by the semi-enclosed Mediterranean Sea. Given the presence of local winds, complex coastlines and orography, high resolution modelling is essential to represent the atmospheric flow and air-sea fluxes that occur in the Mediterranean (Gibelin and Déqué 2003; Gao et al. 2006; Giorgi and Lionello 2008; Herrmann et al. 2011). The ocean-atmosphere coupling is also important for climate studies over the Mediterranean region because of the role of the response of the Mediterranean sea surface temperature (SST, e.g. Somot et al. 2008; Artale et al. 2010). For that reason, several recent studies have used ocean-atmosphere coupled RCMs, such as EBU-POM (Krzic et al. 2011), ALADIN-Climat (Herrmann et al. 2011), PROTHEUS (Mariotti and Dell'Aquila 2012) and LMDz-NEMO-Med (L'Hévéder et al. 2012). However, for the time no multi-year simulation including both ocean-atmosphere coupling and aerosol radiative forcing has been done over the Mediterranean region to our knowkledge. At the global scale, the feedback 
of the SST to aerosol dimming has already been proven recently to reinforce the cooling due to dust aerosols (Martinez-Avellaneda et al. 2010; Yue et al. 2011). The North-Atlantic ocean SST is particularly influenced by dust emissions over West Africa (Evan et al. 2009, 2011). Seasalt (Yue and Liao 2012) and carbonaceous aerosols (Hsieh et al. 2013) are also responsible for decreasing SST and ensuing climate feedbacks.

In this study the objective is to assess the direct and semi-direct effects of aerosols on the regional climate of the Mediterranean, as well as their role in the radiationatmosphere-ocean interactions, using a fully coupled regional climate system model, namely CNRM-RCSM4. This RCSM including atmosphere, ocean, rivers and land surfaces is described in Sect. 2, and evaluated against observations for different meteorologic parameters in Sect. 3. The impact of aerosols on Mediterranean climate is presented in Sect. 4 using a multi-year simulation (2003-2009), associated with a focus on two specific cases in July 2006 and June 2007 highlighting aerosol feedbacks (Sect. 5), before the concluding remarks in Sect. 6.

\section{Methodology}

\subsection{The CNRM regional climate system model: CNRM-RCSM4}

The present work has been carried out with the fully coupled regional climate system model developed at CNRM. It includes the regional climate atmospheric model ALADINClimate (Radu et al. 2008; Déqué and Somot 2008; Farda et al. 2010; Colin et al. 2010; Herrmann et al. 2011), the land-surface model ISBA (Noilhan and Mahfouf 1996), the river routing scheme TRIP (Decharme et al. 2010) and the regional ocean model NEMOMED8 (Beuvier et al. 2010). We use here the version 5.2 of ALADIN-Climate, which has a similar physical package to the global climate model ARPEGE-Climate (Voldoire et al. 2012) used in the CMIP5 exercise. It is a bi-spectral semi-implicit semilagrangian model, with a $50 \mathrm{~km}$ horizontal resolution. ALADIN includes the Fouquart and Morcrette radiation scheme (FMR15, Morcrett 1989), based on the ECMWF model incorporating effects of greenhouse gases, direct effects of aerosols as well as the first indirect effect of sulfate aerosols (Twomey 1977). More information about the other parameterizations used is presented in Farda et al. (2010). Contrary to the globe, the domain is not periodic, so a bi-periodicization is achieved in gridpoint space by adding a so-called extension zone used only for Fourier transforms. The non-linear contributions to the equations are performed in gridpoint space. The domain chosen for this study is presented in Fig. 1, includes the official

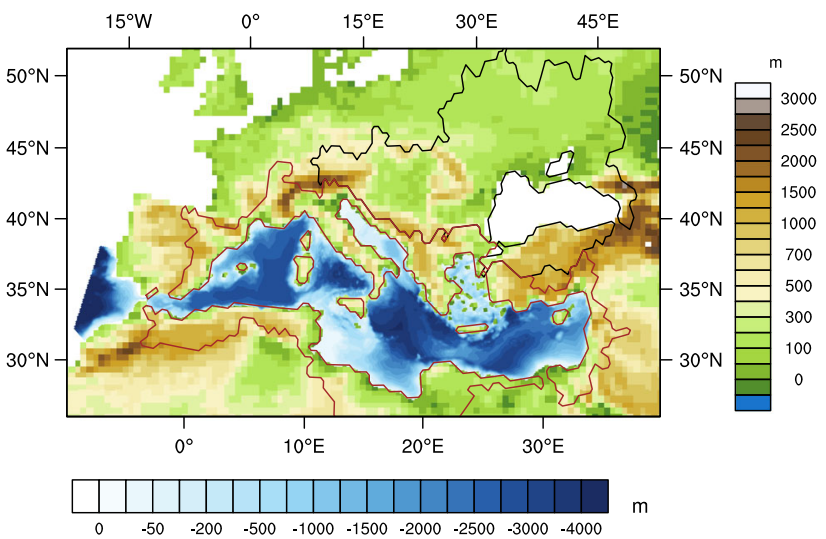

Fig. 1 The regional climate modeling system CNRM-RCSM4. Elevation over land (ALADIN-Climate, right color bar, m), bathymetry over the Mediterranean Sea (NEMOMED8, bottom color bar, m) and the two catchment basins (TRIP, red line for the Mediterranean Sea, and black line for the Black Sea)

domain of the Med-CORDEX program, and represents 90x128 points, including a 11-point wide bi-periodization zone in addition to the more classical 8-point wide relaxation zone using the Davies technique.

The ocean model NEMOMED8 (Beuvier et al. 2010) is the regional eddy-permitting version of the NEMO-V2.3 ocean model (Madec 2008). NEMOMED8 covers the Mediterranean Sea (without the Black Sea) plus a buffer zone including a part of the near Atlantic Ocean, where a three-dimensional damping is performed towards temperature and salinity (monthly data, NEMOVAR-COMBINE reanalysis, Balmaseda et al. 2010), so that the circulation through the strait is simulated with realistic Atlantic waters. A sea level relaxation is also applied on this Atlantic part of the domain towards the same reanalysis. This version has a horizontal resolution of $1 / 8^{\circ} \times 1 / 8^{\circ} \cos ($ lat), namely between 9 and $12 \mathrm{~km}$, and 43 vertical levels, with layer thickness increasing from $6 \mathrm{~m}$ to $200 \mathrm{~m}$. Its grid is tilted and stretched at the Gibraltar Strait to better follow the SW-NE axis of the strait and to increase the local resolution up to $6 \mathrm{~km}$. The partial steps definition of the bottom layer is used, and the surface is parameterized with the free surface configuration, filtered formulation. Figure 1 shows the bathymetry of NEMOMED8 over the Mediterranean Sea.

The TRIP river routing model, developed by Oki and Sud (1998), is used here to convert the simulated runoff by the ISBA land surface scheme into river discharge using a river channel network at $0.5^{\circ}$ resolution (Decharme et al. 2010; Szczypta et al. 2012). It is based on a single prognostic reservoir whose discharge is linearly related to the river mass, using a uniform and constant flow velocity. The $0.5^{\circ}$ grid is cut on a domain that covers the whole drainage area of the Mediterranean and the Black Sea (represented respectively in red and black in Fig. 1), except for the Nile 
river basin for which climatological values are used. Coupling between all the different components is achieved by the OASIS3 coupler (Valcke 2013) at a one day frequency. The flux scheme is based on the work of Louis (1979) for the boundary layer turbulence physics, while the interpolation of the wind speed from the first layer of the model (about $30 \mathrm{~m}$ ) to the $10 \mathrm{~m}$ height follows Geleyn (1988). This model configuration called CNRM-RCSM4 (see the technical note for details, Sevault et al. 2013) is involved in the Med-CORDEX (www.medcordex.eu) and HyMeX (www.hymex.org) programmes. The main difference between the version of Sevault et al. (2013) and the one used in the present study is that spectral nudging is not applied in the latter.

\subsection{Aerosols}

The model ALADIN-Climate incorporates a radiative scheme to take into account the direct and semi-direct effects of five aerosol types (sea salt, desert dust, sulfates, black and organic carbon aerosols) through AOD climatologies. In the previous studies using this model, the climatology used was Tegen et al. (1997). In a recent paper (Nabat et al. 2013), this climatology has been compared to other data sets over the Mediterranean region, showing its limits, notably in underestimating desert dust. Nabat et al. (2013) have proposed a new AOD monthly interannual climatology over the period 2003-2009, based on a combination of satellite-derived and model-simulated products. The satellite instrument MODIS has indeed the best scores against ground-based measurements from AERONET, but does not enable to separate the aerosol content into different species. Consequently, models, which are able to reproduce the main aerosol patterns over the basin, have been included in this new data set: the regional climate model RegCM-4 (Giorgi et al. 2012) for dust and sea-salt aerosols, and the MACC reanalysis (Benedetti et al. 2011) for sulfates, black and organic carbons. The aim is to have the best possible estimation of the atmospheric aerosol content for these five most relevant species. More details about the construction of this new climatology, which is used in the present work, can be found in Nabat et al. (2013). Its main patterns will be presented in Sect. 4.1.

\subsection{Simulations}

Different configurations have been used for simulations in the present work, depending on the presence of aerosols, and on the use of the whole RCSM or the atmospheric model only (see Table 1). The simulation defined as the reference for this study, called C-AER, has used the fully coupled RCSM described previously with the mentioned aerosol fields. The lateral boundary conditions are provided
Table 1 Configuration of the different simulations in this study. (OA = ocean-atmosphere)

\begin{tabular}{lllll}
\hline Simulation & C-AER & F-AER & C-NO & F-NO \\
\hline OA coupling & Yes & No & Yes & No \\
Aerosols & Yes & Yes & No & No \\
\hline
\end{tabular}

by the ERA-INTERIM reanalysis (Dee et al. 2011). The simulation covers the period 2003-2009, after a spin-up period of 2 years (beginning in 2001) with the identical configuration, which is necessary to stabilize the land surface (notably soil moisture) and surface ocean. This spin-up period begins after an initial spin-up of 48 years to get a stabilized ocean. An ensemble of 6 simulations has been carried out using the same methodology, with different initializations of the atmosphere in 2001. The atmospheric conditions of the six members have been taken from January months from previous years. The objective is to address aerosol-climate issues without depending on the internal variability of the RCM (Christensen et al. 2001; Lucas-Picher et al. 2008). Indeed, because of non-linearities in the climate system, small differences in the initial state can have important consequences in the simulations (Laprise 2008).

Simulations have also been carried out without aerosols (C-NO), and with the atmospheric model only (F-AER with aerosols, and F-NO without aerosols). Ensembles of 6 simulations have also been achieved with the configurations $\mathrm{F}-\mathrm{AER}, \mathrm{C}-\mathrm{NO}$ and $\mathrm{F}-\mathrm{NO}$, including for every one the 2-year spin-up period. The idea is to compare C-AER with C-NO in order to study the effect of removing aerosols in the simulation, and to compare F-AER and F-NO to estimate the aerosol effect in forced simulations compared to the aerosol effect in fully coupled simulations. The 6-member ensembles (24 simulations in total) will allow a better estimate of the robustness of the results.

\subsection{Observational data}

In order to evaluate the performance of CNRM-RCSM4, we use several datasets from ground-based measurements and satellite products. The European daily high-resolution gridded data set E-OBS (Haylock et al. 2008) provides surface temperature and is based on about 2,300 groundbased stations. The Climatic Research Unit (CRU) of the University of East Anglia (Harris et al. 2013) provides 2mtemperature and precipitation at a $0.5^{\circ} \times 0.5^{\circ}$ resolution in the version TS3.1 used in the present work. It includes most of the land weather stations data around the world. Precipitation will be also compared to the GPCC product (Schneider et al. 2008), a homogenised gridded monthly precipitation dataset at $0.5^{\circ}$ resolution. Surface radiation is evaluated against ground-based measurements from the 
GEBA (Gilgen and Ohmura 1999) and BSRN networks (Ohmura et al. 1998), as well as against satellite data, namely Surface Radiation Budget (SRB) and International Satellite Cloud Climatology Project (ISCCP). SRB data used in the present work comes from the NASA Global Energy and Water-cycle Experiment (GEWEX) SRB project (version 3.0 : GEWEX and QC products), and provides surface radiation at $1^{\circ} \times 1^{\circ}$ resolution (Stackhouse et al. 2000). The ISCCP provides radiance measurements with a spatial resolution of $2.5^{\circ} \times 2.5^{\circ}$ (Zhang et al. 2004). At the top of the atmosphere (TOA), radiation is compared to Clouds and the Earths Radiant Energy System (CERES)Energy Balanced and Filled (EBAF) data (Loeb et al. 2009) at a $1^{\circ} \times 1^{\circ}$ resolution.

Sea-surface temperature observations are given by Marullo et al. (2007), which is a product based on daily series of optimally interpolated SST maps at high resolution $\left(1 / 16^{\circ}\right)$ computed from time series of satellite infrared AVHRR. Sensible and latent heat fluxes will be evaluated against reconstructions from the objectively analyzed airsea fluxes (OAFlux). This product (Yu et al. 2008) provides a global analysis of the ocean latent and sensible heat fluxes at a $1^{\circ} \times 1^{\circ}$ resolution, based on satellite observations, surface moorings, ship reports and atmospheric model reanalysed surface meteorology. Comparisons between these gridded data sets and CNRM-RCSM4 will be presented in the following section, using averages on different zones (EURS, EURN, ...) defined in Fig. 2.

\section{General performance of CNRM-RCSM4}

Before investigating the impact of aerosol forcing on climate, CNRM-RCSM4 must be evaluated in terms of ability to reproduce the main patterns of the climatology over the region. The simulation $\mathrm{C}$-AER, considered as the reference, is evaluated in this section. Temperature $(2 \mathrm{~m}$ and SST), precipitation, cloud cover, SW and LW downward radiative fluxes, latent and sensible heat fluxes, sea level pressure as well as surface wind are compared against different observations. Every field of CNRM-RCSM4 presented in this section is averaged over the period of the corresponding observation and over the six members of the simulation ensemble. Only significant differences at the level 0.05 are plotted. Figure 2 a presents the winter and summer averages for $2 \mathrm{~m}$-temperature difference between $\mathrm{C}$-AER and CRU over land surfaces. In winter a cold bias of $-2.4^{\circ} \mathrm{C}$ is observed in EURS, $-1.8^{\circ} \mathrm{C}$ in AFRW and $-2.0^{\circ} \mathrm{C}$ in MDE. This bias is weaker over central $\left(-0.8^{\circ} \mathrm{C}\right)$ and northern $\left(-0.5^{\circ} \mathrm{C}\right)$ Europe. In summer, ALADIN is on the contrary affected by a warm bias in northern Africa (AFRW-AFRE: $0.9^{\circ} \mathrm{C}$ on average) and central Europe (EURC: $1.1^{\circ} \mathrm{C}$ ). Persisting snow is responsible for a cold bias in summer over the higher elevations (notably the Alps). The monthly means of 2 m-temperature of C-AER, CRU, ERA-INTERIM and E-OBS are presented in Fig. 3a for six regions of the Mediterranean area defined in Fig. 2a. $\mathrm{C}$-AER is able to reproduce the seasonal cycle over each region compared to $\mathrm{CRU}$ and EOBS data sets. The cold bias in winter is confirmed over all the regions except EURN, the same for the warm bias in summer except over MDE and EURN. ERA-INTERIM, which is the data set used as atmospheric lateral boundary conditions, is very close to CRU.

Over the Mediterranean Sea, Fig. 2b presents the evaluation of NEMO SST in winter and summer compared to the Marullo data, and Fig. 3b for monthly means compared to the Marullo and ECMWF data sets. In winter, no significant bias has been found over the western basin, the Adriatic and the Aegean seas, whereas the Ionian and Levantin basins are affected by a weak negative bias of $0.5^{\circ} \mathrm{C}$. In summer, the negative bias is more important and concerns the whole Mediterranean sea $\left(-0.7{ }^{\circ} \mathrm{C}\right.$ on average). This negative bias could be partly explained by the fact that in the model, SST is calculated as the mean temperature of the first six meters whereas measurements consider SST as the temperature of water surface. The reanalysis from the ECMWF, shows an SST very close to Marullo (Fig. 3b). This dataset is used for the SST in forced simulations (atmospheric model only) of the present work.

In the same way as for 2 m-temperature, Figs. $2 \mathrm{c}$ and $3 \mathrm{c}$ present respectively the winter and summer average precipitation difference between C-AER and CRU over land surfaces, and the monthly means of precipitation over six regions. ALADIN seems to overestimate precipitation over northern Europe in winter $(+0.4 \mathrm{~mm} /$ day on average in EURN) especially over higher elevations (Alps, Pyrenees, Carpathians). The maximum is simulated in April by ALADIN instead of July (CRU) or August (GPCC) in the observations. Northern Africa is subject to a negative bias in winter $(-0.3 \mathrm{~mm} /$ day $)$. In summer, central Europe is on the contrary affected by a lack of precipitation in ALADIN $(-0.3 \mathrm{~mm} /$ day in EURC, up to $-1 \mathrm{~mm} /$ day in August), already revealed in other RCMs (summer drying problem, Hagemann et al. 2004). This could be due to deficiencies in the soil moisture scheme, which tends not to keep enough water in spring, thus inhibiting convection. In addition, we argue that too much $\mathrm{SW}$ radiation (see below) can empty the soil moisture buckets in spring in the model too early, thus having not enough soil water in summer and this way inhibiting also convection (Wild et al. 1996). GPCC and ERA-INTERIM are similar to CRU, except over northern Africa (AFRW and AFRE) where ERA-INTERIM precipitation has a negative bias similar to ALADIN. 
(a) Land 2m-temperature

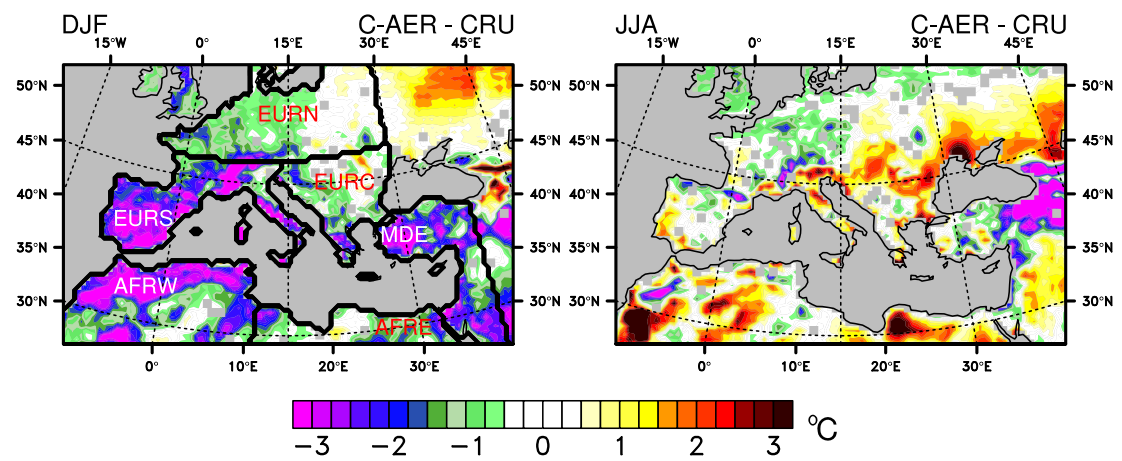

(b) Sea Surface Temperature

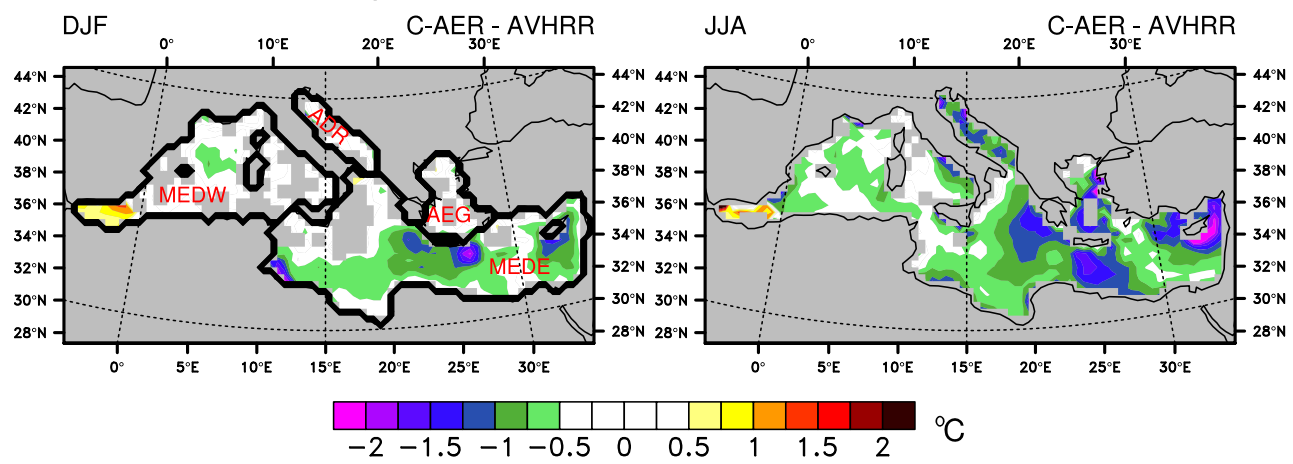

(c) Precipitation

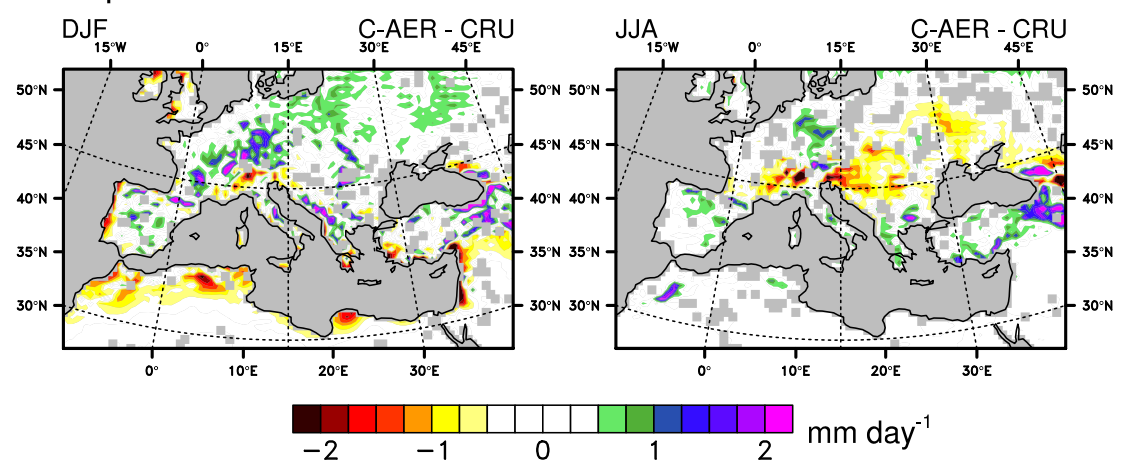

(d) Cloud cover

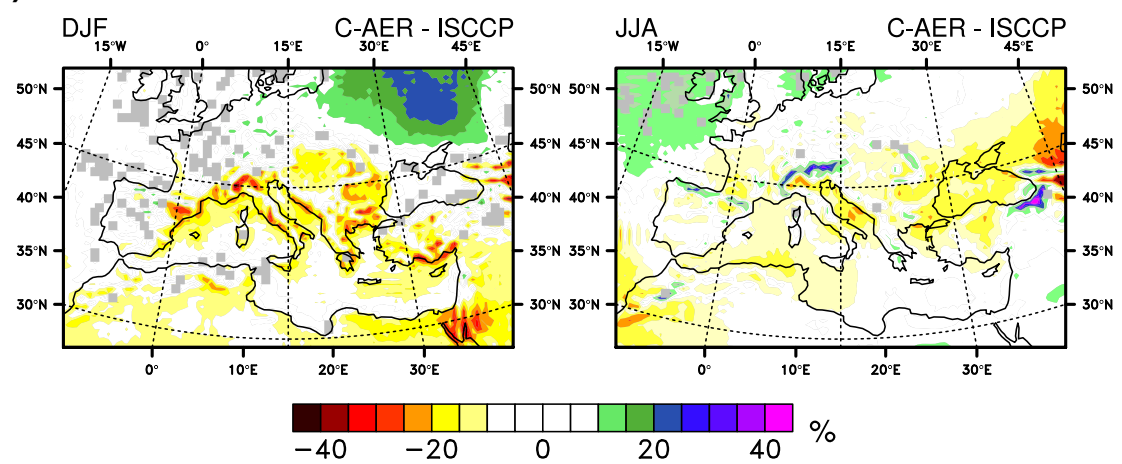

Fig. 2 Winter (DJF, left) and summer (JJA, right) average biases for 2 m-temperature $\left({ }^{\circ} \mathrm{C}\right.$, a), sea surface temperature $\left({ }^{\circ} \mathrm{C}, \mathbf{b}\right)$, precipitation $(\mathrm{mm} /$ day, $\mathbf{c})$ and cloud cover $(\%, \mathbf{d})$. Biases are calculated as the differences between C-AER and CRU (a and c), Marullo dataset (b) and ISCCP (d) over the period 2003-2009. Only significant values at the level 0.05 are plotted 
(a)
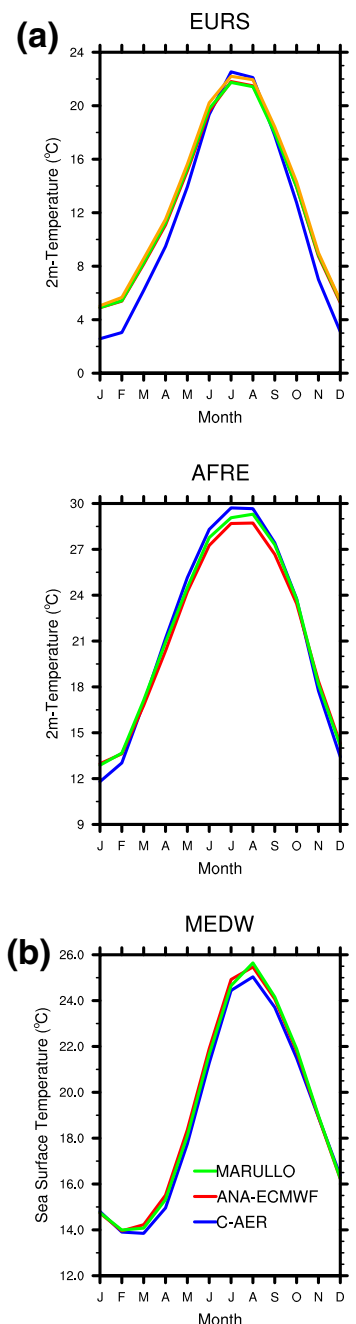

(c)
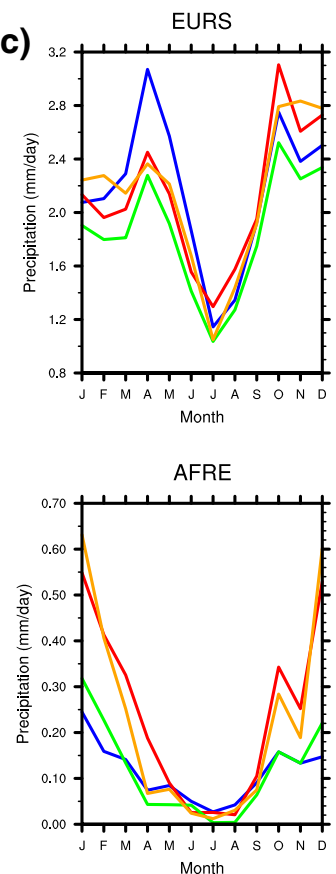
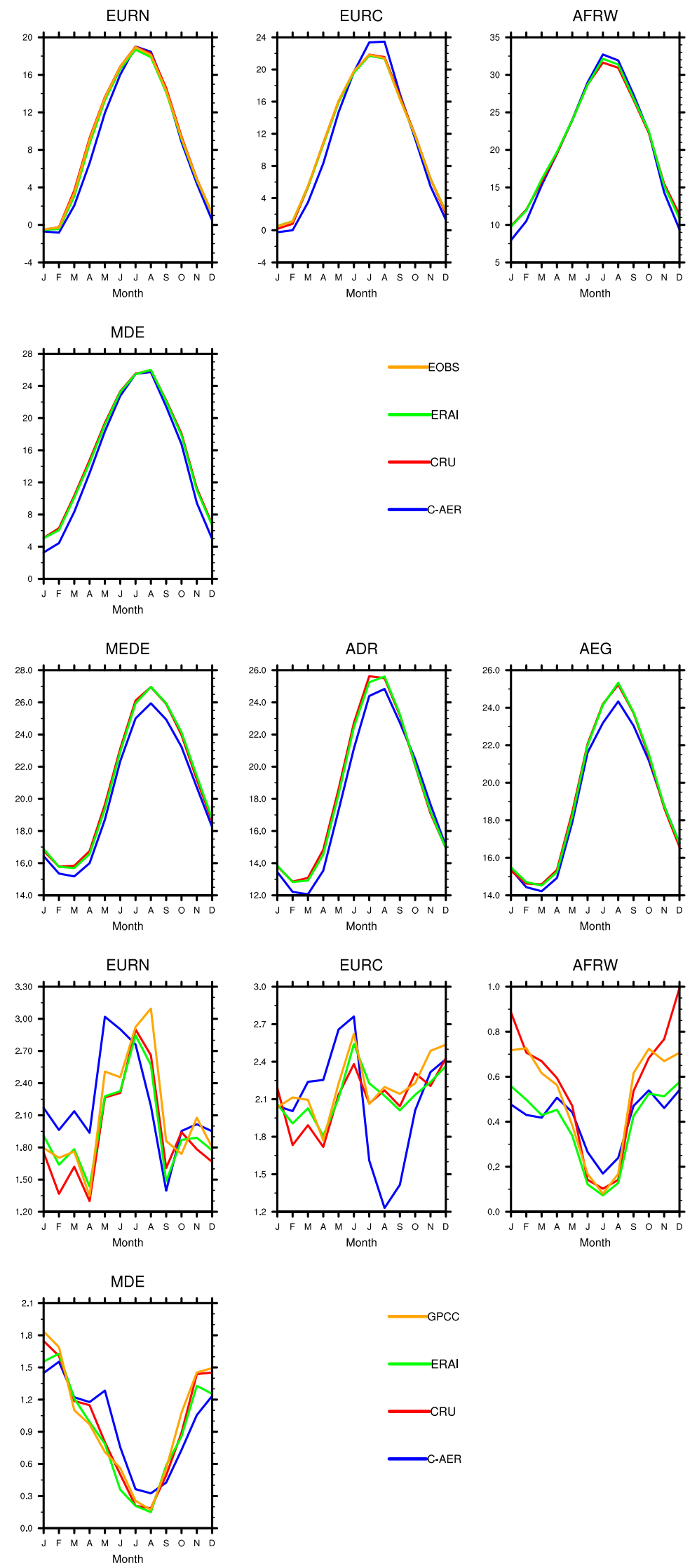
4Fig. 3 a Monthly average $2 \mathrm{~m}$-temperature $\left({ }^{\circ} \mathrm{C}\right)$ for C-AER and different data sets over the period 2003-2009 over six land regions (see definition in Fig. 2a). b Same as a but for sea surface temperature $\left({ }^{\circ} \mathrm{C}\right)$ over 4 ocean regions for the period 2003-2007 (see definition in Fig. $2 b$ ). c Same as a but for precipitation (mm/day) over six land regions for the period 2003-2009. The confidence interval at the level 0.05 calculated from the ensemble spread is for all the regions and months $\pm 0.0^{\circ} \mathrm{C}$ for $2 \mathrm{~m}$ and sea surface temperature, and $\pm 0.0 \mathrm{~mm} /$ day for precipitation

With regards to cloud cover in Fig. 2d, CNRM-RCSM4 is clearly affected by a general deficit in clouds, especially over the Mediterranean Sea and the surrounding coastal regions. In winter, an overestimation of the cloud cover can however be noted in the north-east of the domain.

In terms of surface downward radiation, Fig. 4 presents the differences with ground-based measurements from the GEBA and BSRN networks for C-AER, ERA-INTERIM and three satellite data sets (SRB GEWEX, SRB QC and ISCCP). In Carpentras (southern France), ALADIN overestimates SW radiation by $12 \mathrm{Wm}^{-2}$ on annual average, up to $20 \mathrm{Wm}^{-2}$ in August, whereas ERA-INTERIM is closer to BSRN, and satellites underestimate radiation. The overestimation of surface solar radiation is a long standing problem in many climate models, first noted in Wild et al. (1995), and then in various intercomparison projects (e.g. Wild 2008). Similar results are obtained for Lindenberg (Germany), with a positive average bias of $8 \mathrm{Wm}^{-2}$ for C-AER. In Sede-Boker (Middle-East) ALADIN is affected by a negative bias in summer but remains close to the ISCCP satellite. Near the Black Sea in Odessa, SW radiation is also overestimated by ALADIN $\left(24 \mathrm{Wm}^{-2}\right.$ on average), as well as by ERA-INTERIM. Over the sea, the bias is inferior to $10 \mathrm{Wm}^{-2}$ compared to the SRB QC product (figure not shown). This positive bias in SW radiation is probably due to a lack of cloud cover in ALADIN as mentioned above, or to an overestimation of clear-sky fluxes due to a lack of water vapor absorption as often found in climate models (Wild et al. 2006). Note that the atmosphere in CNRM-RCSM5 has not strong biases in integrated water content. A misrepresentation of the seasonal cycle of cloud cover has also been noticed in CNRMRCSM4, explaining a higher bias in SW radiation in summer. In addition, possible errors in the aerosol climatology used in CNRM-RCSM4 could also affect this bias, notably in the Sede-Boker site. These conclusions should be however moderated by considering the question of the representativeness of the station in a $50-\mathrm{km}$ resolution model. With regards to downward LW radiation, the three stations show that ALADIN has a negative bias: $-18 \mathrm{Wm}^{-2}$ in Carpentras, $-2 \mathrm{Wm}^{-2}$ in Lindenberg and $-4 \mathrm{Wm}^{-2}$ in Sede-Boker, which is more important in winter (up to $-26 \mathrm{Wm}^{-2}$ in Carpentras) than in summer. This could also be linked to the lack of cloud cover in
ALADIN, and inaccuracies in the simulation of the water vapour continuum (Wild et al. 1995, 2001). It should be also noted that satellite products show a relative high dispersion (see Fig. 4).

At TOA, ALADIN has been evaluated against satellite retrievals from the CERES mission: the difference between ALADIN and CERES is presented in Fig. 5 for SW (a) and LW (b) radiation. Over land surfaces, CNRM-RCSM4 has a negative SW bias, reaching $-16 \mathrm{Wm}^{-2}$ in northern Africa and $-8 \mathrm{Wm}^{-2}$ in Europe in summer. Deficiencies in surface albedo or in cloud cover as mentioned above with consequences on albedo, might explain this negative bias at TOA. Over the Mediterranean Sea, TOA SW radiation is closer to CERES (only $-3 \mathrm{Wm}^{-2}$ on average). The bias in LW radiation is positive over the whole domain, but the relative error is lower than for SW radiation.

As the present study allows to investigate feedbacks of aerosol forcing on air-sea fluxes, the evaluation of sensible and latent heat fluxes over the Mediterranean Sea is presented in Fig. 6. Comparisons have been made using the OAFLUX satellite data. ALADIN sensible heat loss is in good agreement with OAFLUX data (a), especially in summer, but this is not the case in winter near the northern coast (Gulf of Lions, Adriatic Sea) where an underestimation of about $20 \mathrm{Wm}^{-2}$ can be noticed. This is possibly partly attributed to observational deficiencies in this very windy area. Another data set, coming from the National Oceanography Centre of Southampton (NOCS, 1980-2004, Berry and Kent 2009) and based on ship observations, presents indeed lower annual latent heat losses in the Adriatic Sea, but unfortunately stops in 2004. The latent heat loss (b) is slightly overestimated by $10 \mathrm{Wm}^{-2}$ in winter and $8 \mathrm{Wm}^{-2}$ in summer on average over the Mediterranean Sea. However the bias is higher at some places (more than $40 \mathrm{Wm}^{-2}$ over the Ionian basin and Aegean Sea) in winter. It is also worth mentionning that uncertainties are inherent in the observational references of both latent and sensible heat fluxes.

Figure 7 shows the evaluation of mean sea level pressure (a) and surface wind (b), respectively, against ERAINTERIM and QuikSCAT data. The CNRM-RCSM4 bias in sea level pressure is lower than $1 \mathrm{hPa}$ on average on the whole domain except the Alps and the Atlas mountains in summer. As for the surface wind, the highest differences are located over the Atlantic ocean which is not coupled. Over the Mediterranean Sea, CNRM-RCSM4 and QuikSCAT are in better agreement except in the Strait of Gibraltar.

In conclusion, the C-AER simulation has proven to be able to simulate the main patterns of the Mediterranean climate, in relative good agreement with observations, despite notably a cold bias in SST, winter temperature and cloud cover (and related radiative biases). 


\section{(a) Surface SW downward radiation}
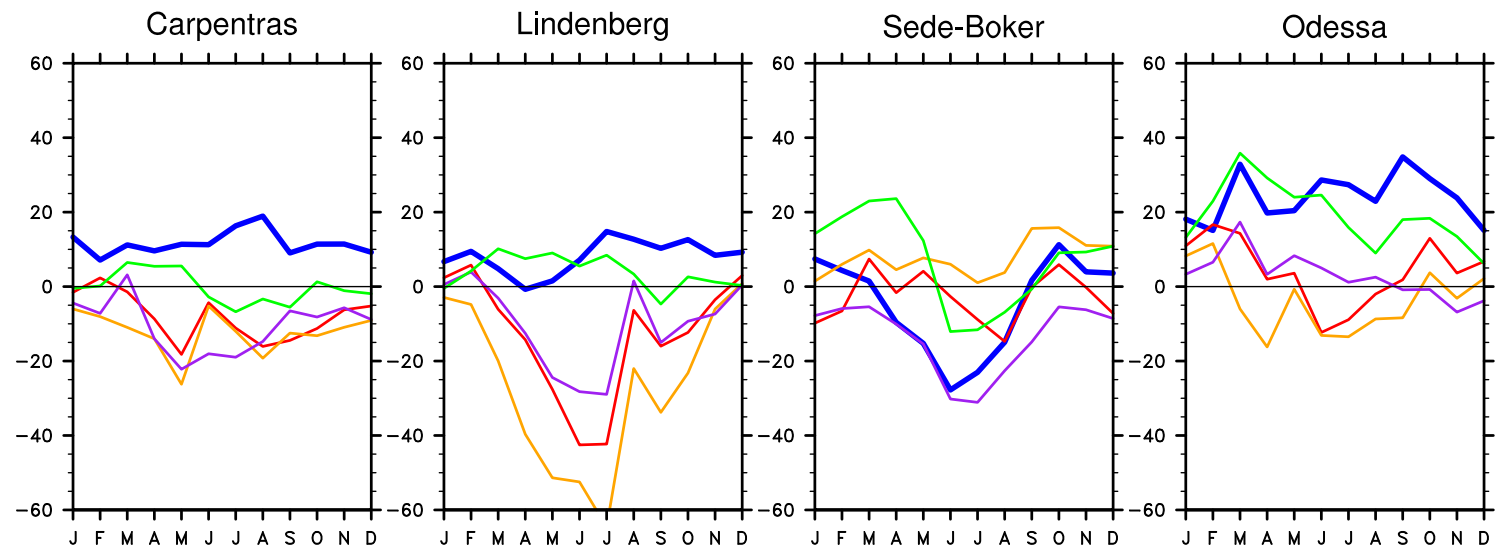

(b) Surface LW downward radiation
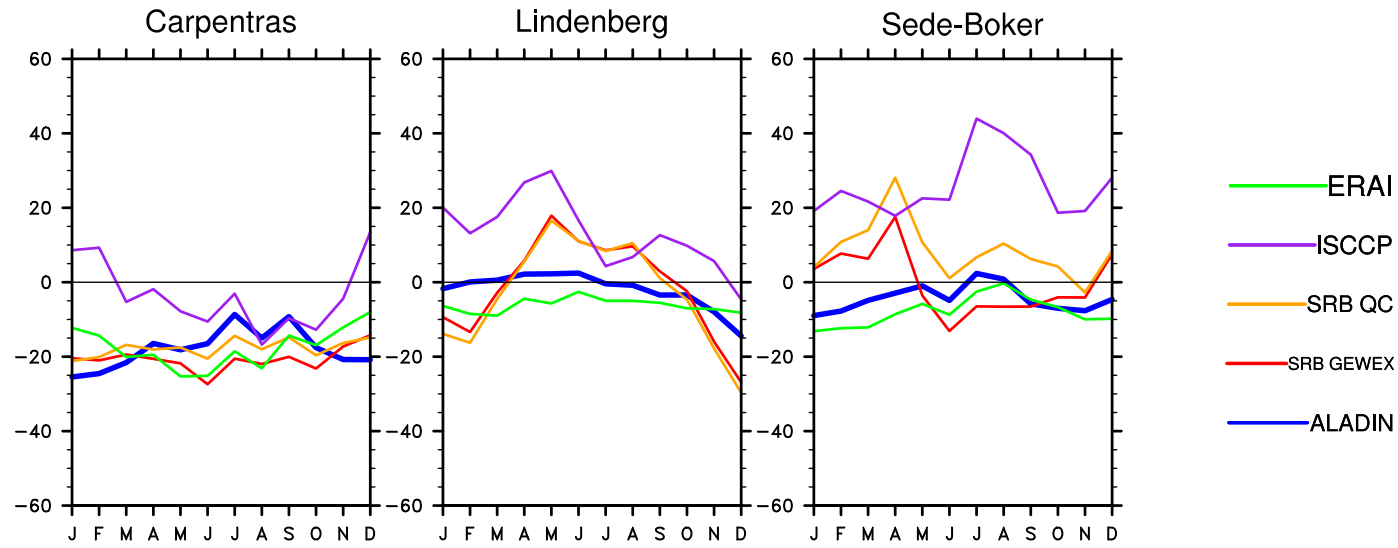

Fig. 4 Surface downward SW (a) and LW (b) radiation difference between C-AER (blue) and ground-based measurements from the BSRN (Carpentras, Lindenberg and Sede-Boker) and the GEBA (Odessa) networks. The maximal confidence intervals at the level 0.05 calculated from the ensemble spread are respectively \pm 1.5 , $\pm 0.7, \pm 3.7$ and $\pm 0.6 \mathrm{Wm}^{-2}$ for the different stations in $\mathrm{SW}$

radiation, and respectively $\pm 0.6, \pm 0.6$ and $\pm 0.5 \mathrm{Wm}^{-2}$ for the different stations in LW radiation. Surface downward SW and LW radiation has been added for three satellite products: SRB GEWEX (red), SRB QC (orange) and ISCCP (purple), as well as for the reanalysis ERA-INTERIM (green)

\section{Aerosol effects on the mean regional climate}

\subsection{Aerosol variability}

This section aims at evaluating the mean direct effect of aerosols on the Mediterranean climate. Simulations have been carried out with CNRM-RCSM4 with (C-AER) and without (C-NO) aerosols. Aerosols are included in ALADIN-Climate using monthly interannual climatologies (Nabat et al. 2013). Figure 8a presents the seasonal average AOD from this climatology over the period 2003-2009, while monthly averages per aerosol type are shown in Fig. 9 over Europe, the Mediterranean Sea and northern Africa. These 3 zones correspond to the merging of the zones defined in Fig. 2, namely respectively EUR$\mathrm{N}+\mathrm{EURS}+\mathrm{EURC}$, MEDW+MEDE+AEG, and AFR$\mathrm{W}+\mathrm{AFRE}$, and will also be used in the following sections. Aerosol content over the Mediterranean region is affected

by a strong seasonal cycle, essentially controlled by desert dust and sulfates. Dust aerosols are indeed transported over the Mediterranean Sea during successing outbreaks, occuring first in spring in the eastern basin, and then moving westwards in summer. These outbreaks are due to intense dust uplift over the Libyan and Egyptian deserts in spring (Moulin et al. 1998) and favourable circulation patterns (Gkikas et al. 2012). In summer, frequent low pressure systems over northern Morocco favour the dust export over the western basin (Moulin et al. 1998). Anthropogenic sulfate aerosols are prevailing over Europe, especially in spring and summer, and can also extend up to the Mediterranean Sea. Local maxima can be noticed in the Po Valley and in central Europe. The other aerosols (organic, carbon and sea-salt aerosols) have weaker AOD. It should be noted that sea salt particles are maximal in winter over the Mediterranean Sea because of the associated strong winds. 


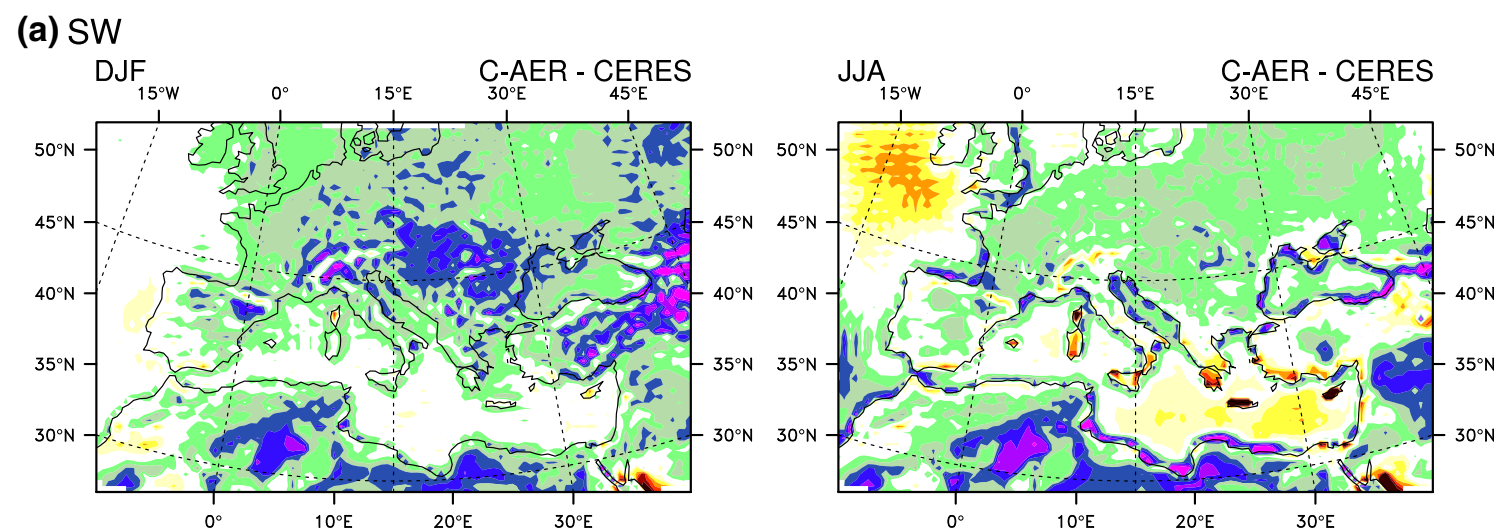

(b) LW

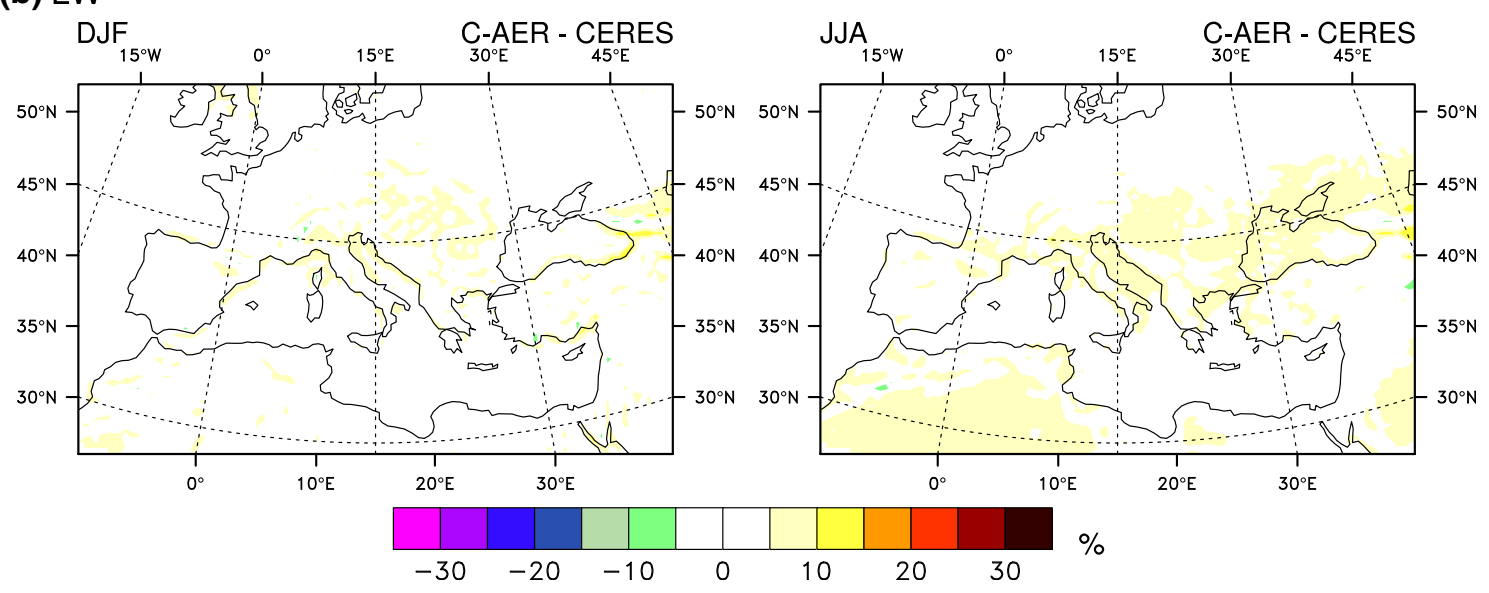

Fig. 5 Winter (DJF, left) and summer (JJA, right) TOA upward SW (a) and LW (b) radiation average relative error (bias/mean, \%) of C-AER against CERES over the period 2003-2009. Only significant values at the level 0.05 are plotted

\subsection{Aerosol direct and semi-direct radiative forcing}

Figure 8 presents the average aerosol net direct radiative forcing (DRF) at the surface and at the TOA for SW (b) and LW (c) radiation calculated in the C-AER simulations. Aerosol DRF is calculated in-line during the simulation by calling radiation code twice (with and without aerosols), in order to have only the direct aerosol effect. Average values of these parameters over Europe, the Mediterranean Sea and northern Africa are indicated in Table 2, while monthly averages per aerosol type are shown in Fig. 9. All these forcings show a strong seasonal cycle similar to the aerosol load (Fig. 8a).

The scattering and absorption of the incident radiation by the various aerosols cause a negative direct radiative forcing in SW radiation at the surface. Over Europe, the surface SW DRF is estimated at $-19.4 \mathrm{Wm}^{-2}$ and reaches its maximum in summer $\left(-25 \mathrm{Wm}^{-2}\right.$ in July). It is dominated throughout the year by the sulfate forcing with a maximum in absolute terms in June, and accentuated in July by organic and dust aerosols (Fig. 9). Even if the dust AOD is stronger than the organic AOD, the organic forcing is higher than the dust one over Europe, because of different optical properties. Organic aerosols notably include black carbon, which is very absorbing. Figure 8 also reveals local maxima in Europe in spring (Po Valley, Benelux) and summer (central Europe) associated with industrial pollution and biomass burning. Over the Mediterranean Sea, sulfates, dust and organic aerosols are responsible for a high surface SW DRF $\left(-20.9 \mathrm{Wm}^{-2}\right.$ on average), especially in spring and summer (Fig. 9). Sulfates are prevailing in spring and autumn, and exert a strong impact on surface radiation because of their weaker asymmetry factor. Figure 9 shows that sea salts have a weaker contribution in the aerosol radiative effect, with a surface forcing maximal in winter $\left(-1 \mathrm{Wm}^{-2}\right)$. Compared to local calculations, Benas et al. (2011) have estimated the total surface SW DRF at $-26 \pm 16 \mathrm{Wm}^{-2}$ in Crete over a long-time period (2000-2010), using calculations performed with a radiative transfer model based on Terra and Aqua MODIS data, which is consistent with C-AER surface SW DRF $\left(-20.3 \pm 0.1 \mathrm{Wm}^{-2}\right.$ on average in Crete). The large difference in the error range comes from the calculation method: Benas et al. (2011) have provided the 
(a) Sensible heat loss

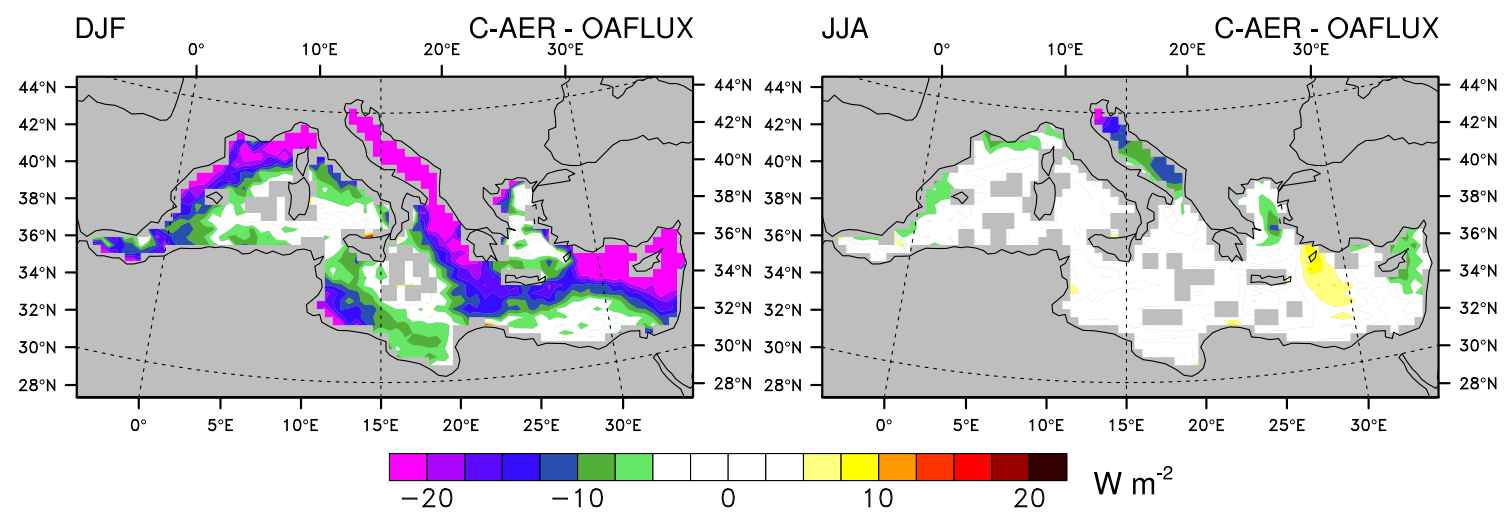

(b) - Latent heat loss

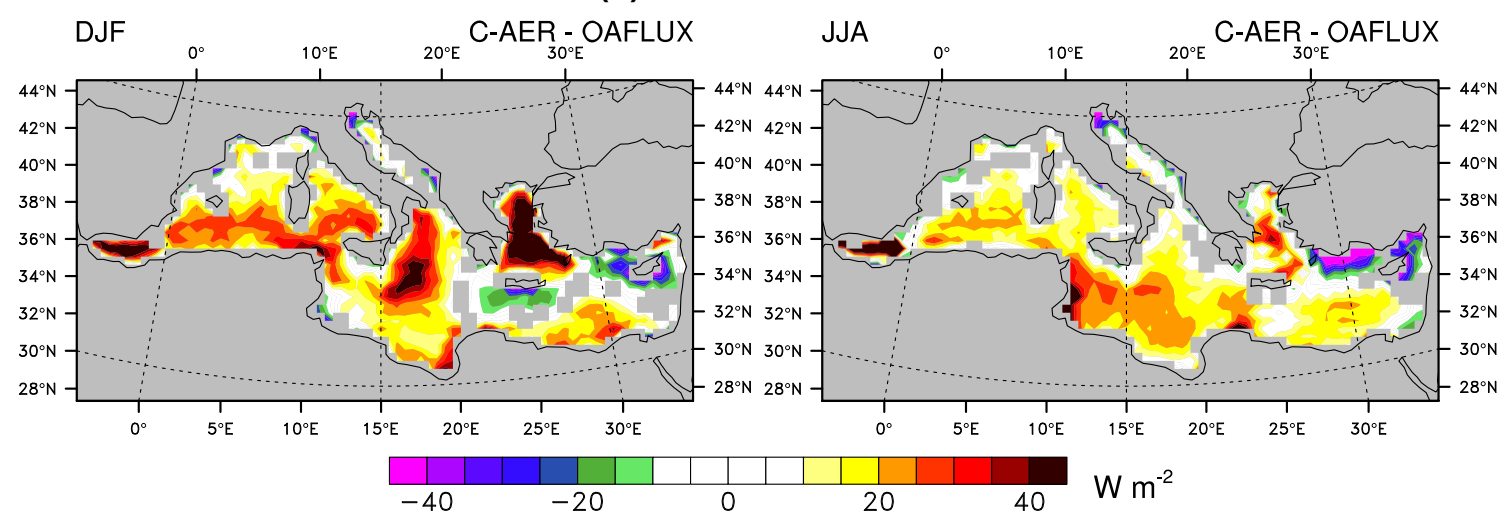

Fig. 6 Winter (DJF, left) and summer (JJA, right) surface sensible (a) and latent (b) heat loss average bias (Wm ${ }^{-2}$ ) for the C-AER simulation. Biases are calculated using OAFLUX for the period 2003-2008 over the Mediterranean Sea. Only significant values at the level 0.05 are plotted

simple standard deviation from instantaneous values whereas we have calculated a confidence interval at the level 0.05 from the 6 members of the simulation ensemble. Over northern Africa dust aerosols lead to a high SW surface DRF in spring $\left(-23.3 \mathrm{Wm}^{-2}\right)$ and in summer $\left(-30.2 \mathrm{Wm}^{-2}\right)$. For the time, such estimations are rare in literature and two previous studies have been added in Table 2. The RegCM columns correspond to values established by Nabat et al. (2012) from a 10-year simulation (2000-2009) using the RCM RegCM-4 (Giorgi et al. 2012). On average, RegCM SW surface radiative forcing is weaker than in ALADIN, certainly due to sulfate aerosols in this RegCM simulation (Nabat et al. 2012) that have been shown to be underestimated over Europe, especially in summer, probably due to the emission datasets. However the seasonal cycle of dust particles notably is similar with a maximum in spring and summer. In addition to RCM estimations, Papadimas et al. (2012) have also calculated the surface SW radiative effect over the broader Mediterranean basin $\left(29-46.5^{\circ} \mathrm{N}, 10.5^{\circ} \mathrm{W}-38.5^{\circ} \mathrm{E}\right)$ over the period 2000-2007 using MODIS observations. Their results are compared in the last two columns of Table 2 against the averages for-C-AER over the same box: results are close to the C-AER simulation at the surface with a slight overestimation by C-AER $\left(-19.9 \mathrm{Wm}^{-2}\right.$ on average for CNRMRCSM4 against $-16.5 \mathrm{Wm}^{-2}$ ).

At the TOA, the SW DRF is also negative in CNRMRCSM4 over the sea $\left(-10.5 \mathrm{Wm}^{-2}\right)$ and Europe $\left(-6.5 \mathrm{Wm}^{-2}\right)$, because of the scattering of the incident radiation by sulfate aerosols in the atmosphere. Over Crete, C-AER estimates it at $-8.4 \mathrm{Wm}^{-2}$ against $-6 \pm 5 \mathrm{Wm}^{-2}$ for Benas et al. (2011). The situation is different over northern Africa where dust aerosols prevail and where the surface albedo is higher. These two elements lead to an enhanced absorption of reflected radiation, hence a positive TOA SW DRF in summer $\left(+0.8 \mathrm{Wm}^{-2}\right)$. Compared to values from Papadimas et al. (2012) and RegCM in table 2 over the broader Mediterranean basin, C-AER TOA forcing is higher, especially over Europe and the Mediterranean Sea, which is probably due to differences in surface albedo.

With regards to LW radiation, only dust aerosols have a significant impact because of their microphysical properties, and notably the presence of coarse dust mode. Sulfate and organic aerosols have weaker effects on LW. Surface 
(a) Sea Level Pressure

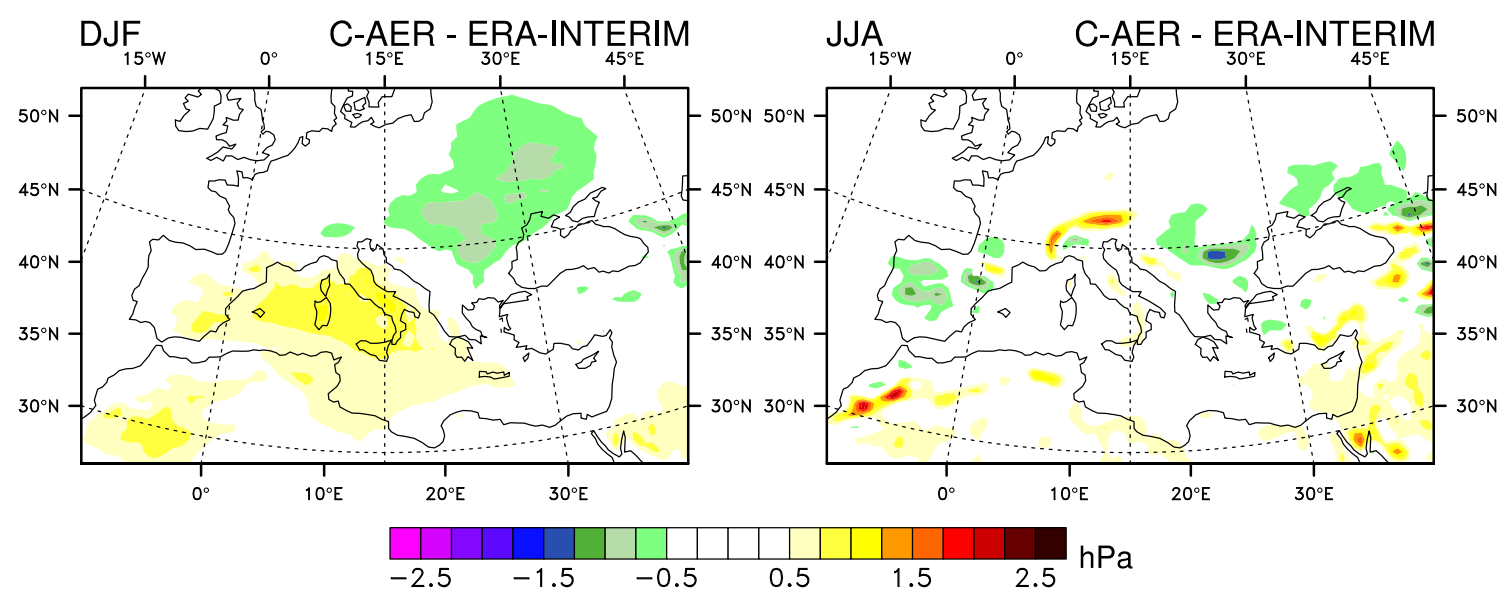

(b) Surface Wind

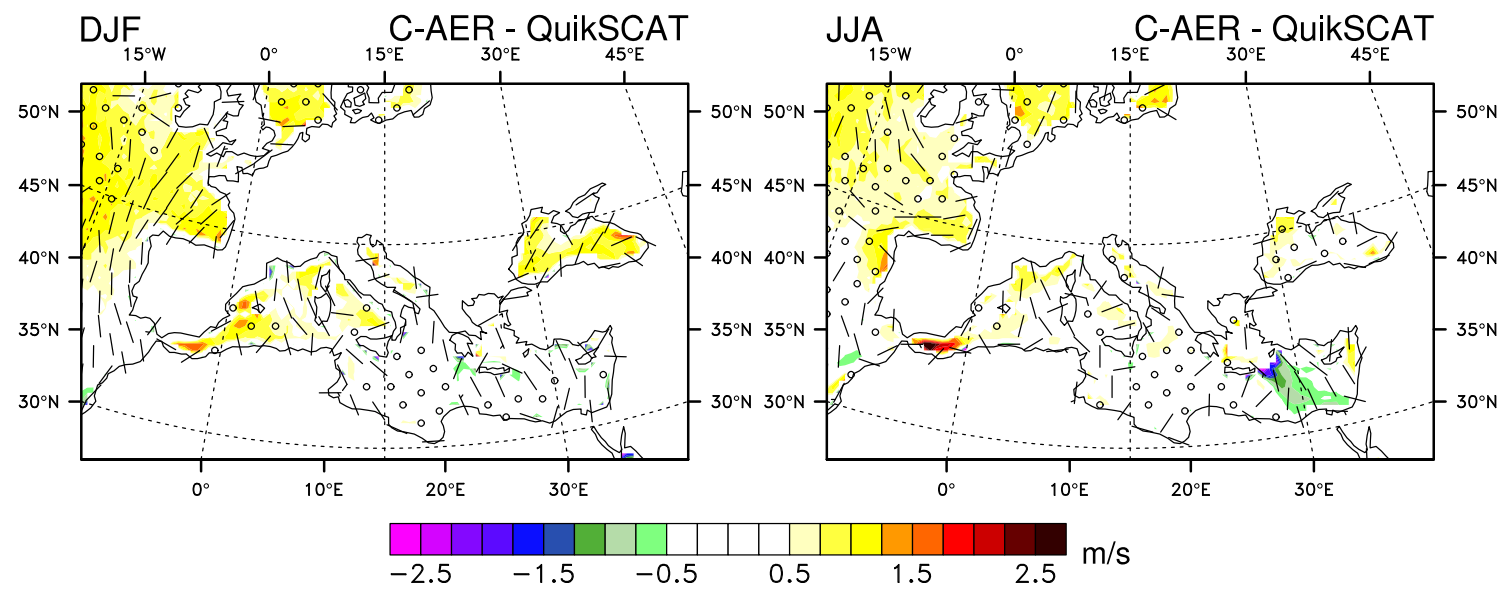

Fig. 7 a Winter (DJF, left) and summer (JJA, right) sea level pressure (hPa) difference between C-AER and ERA-INTERIM over the period 2003-2009. Only significant values at the level 0.05 are plotted.

and TOA LW RF are consequently higher in northern Africa in summer, reaching +4.8 and $+3.1 \mathrm{Wm}^{-2}$, respectively. RegCM averages are similar over Europe and the Mediterranean Sea, but higher at the surface over northern Africa $\left(+6.5 \mathrm{Wm}^{-2}\right.$ in summer for $\left.\operatorname{RegCM}\right)$. Uncertainties in the dust LW absorption coefficient are probably responsible for this difference. It should be recalled here that the LW scattering effect of mineral dust is not taken into account in CNRM-RCSM4 (Dufresne et al. 2002).

Figure 10 presents the semi-direct aerosol effect, resulting from calculations achieved thanks to the C-NO simulations. The SW (resp. LW) semi-direct effect has been calculated as the difference between the effect of aerosols on SW (LW) radiation (i.e. C-AER-C-NO) and the SW (LW) DRF. The SW surface semi-direct effect (Fig. 10a) is globally weaker than the direct effect, b Same as a but for surface wind (m/s) over the period 2003-2006 compared to QuikSCAT data. One wind barb represents $2 \mathrm{~m} / \mathrm{s}$, circles indicating differences lower or equal to $1 \mathrm{~m} / \mathrm{s}$

reaching $+5.7 \mathrm{Wm}^{-2}$ on average over the Mediterranean Sea, $+5.0 \mathrm{Wm}^{-2}$ over Europe and $+4.7 \mathrm{Wm}^{-2}$ over northern Africa at the surface for SW radiation, but contributes to reduce the negative aerosol radiative forcing. This is due to changes in cloud cover and circulation as explained in more details in the following section. In terms of surface downward LW radiation (Fig. 10b), semi-direct effect is limited (on average $-0.1 \mathrm{Wm}^{-2}$ over the Mediterranean Sea, $+0.6 \mathrm{Wm}^{-2}$ over Europe and $+2.0 \mathrm{Wm}^{-2}$ over northern Africa). This LW effect is also probably related to changes in cloud cover by aerosols (see Sect. 4.3).

As a result the total aerosol net SW effect at the surface (direct plus semi-direct) simulated in CNRM-RCSM4 is negative, reaching on average $-15.1 \mathrm{Wm}^{-2}$ over the Mediterranean Sea, $-9.7 \mathrm{Wm}^{-2}$ over Europe and $-14.7 \mathrm{Wm}^{-2}$ over northern Africa. 
(a) - AOD

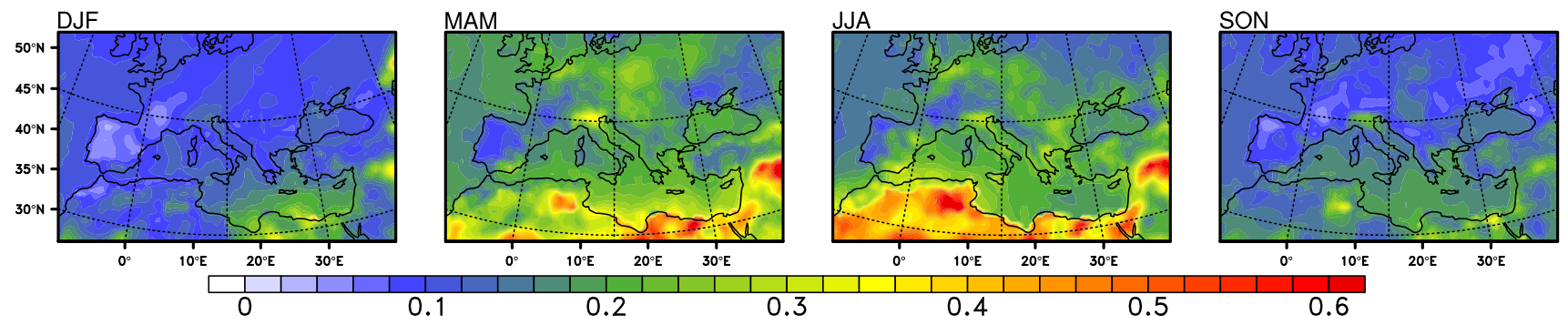

(b) - Aerosol Direct Radiative Forcing SW
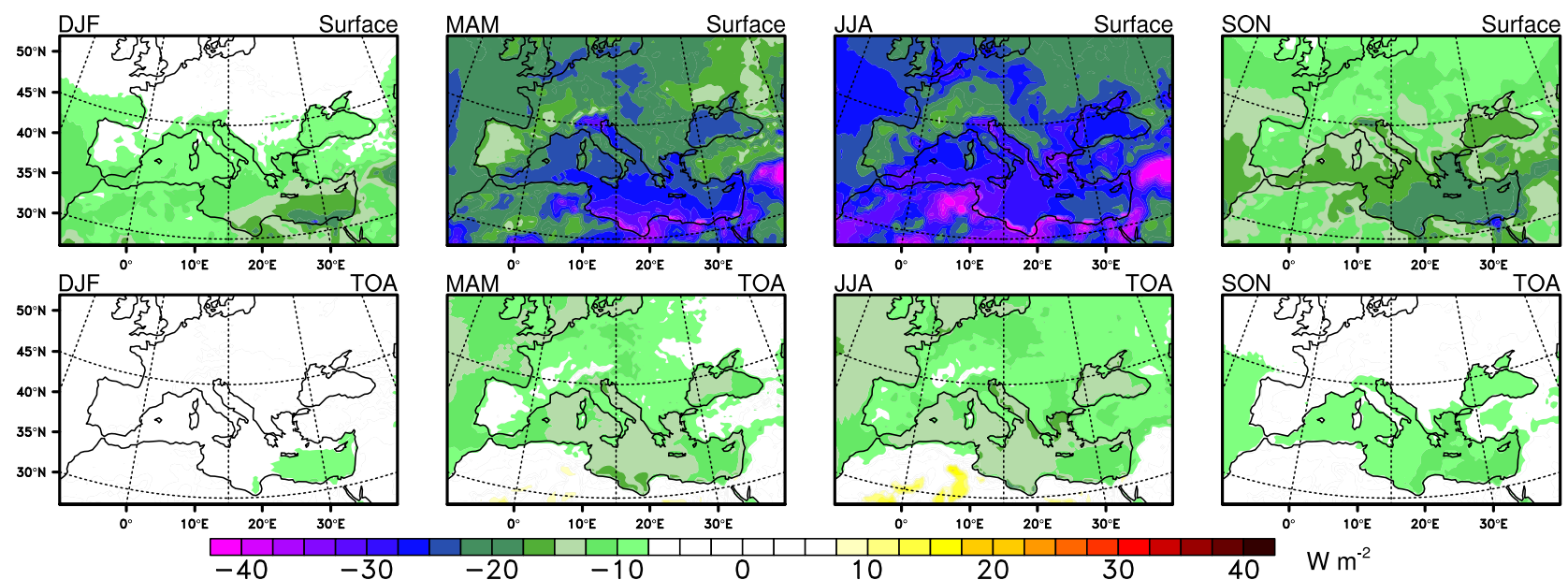

(c) - Aerosol Direct Radiative Forcing LW
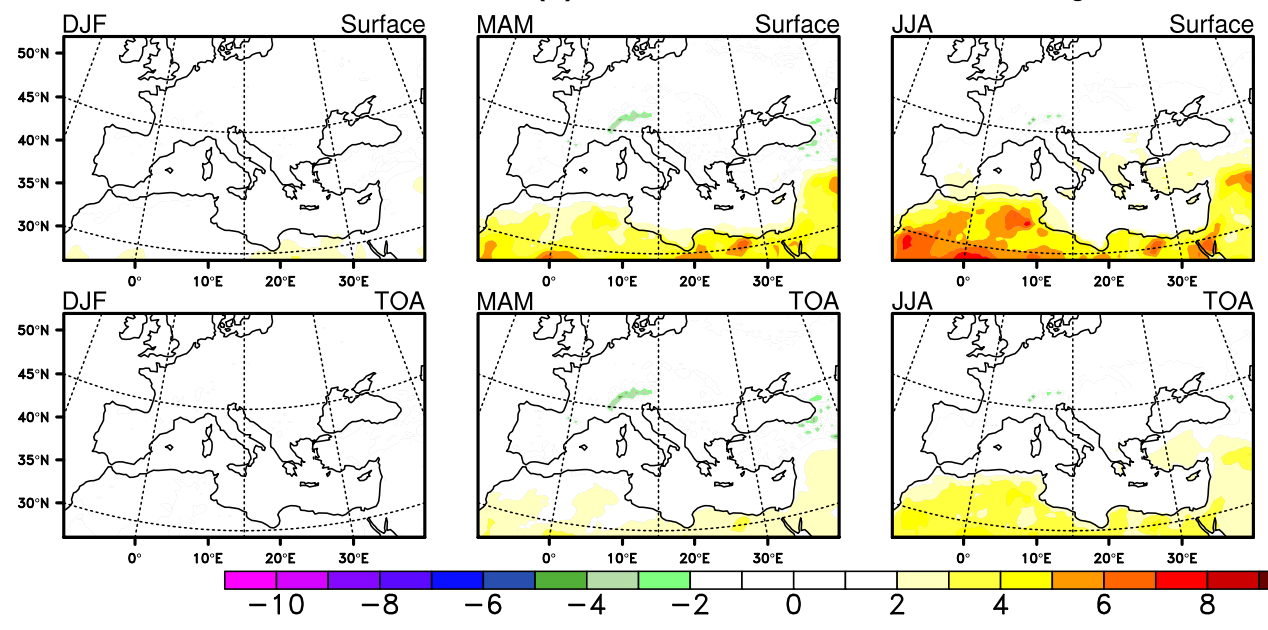

Fig. 8 Average seasonal aerosol optical depth at $550 \mathrm{~nm}$ (a) and direct radiative forcing $\left(\mathrm{Wm}^{-2}\right)$ in SW (b) and LW (c) radiations at the surface and at TOA for the C-AER simulation ensemble mean. For (b) and (c), only significant values at the level 0.05 are plotted

\subsection{Impact of aerosol forcing on the Mediterranean climate variability}

After these direct and semi-direct radiative forcing calculations, the comparison with the C-NO simulation now enables to estimate the consequences for different meteorological parameters as well as ocean-atmosphere fluxes. Figure 11 presents the seasonal average difference between
C-AER and C-NO in terms of 2m-temperature (a), SST (b), sensible (c) and latent (d) heat loss, surface specific humidity (e), precipitation (f), cloud cover (g) and sea surface salinity (h). First, the negative surface radiative forcing described in the previous paragraph has repercussions on surface temperature. Over Europe, Fig. 11a shows that $2 \mathrm{~m}$-temperature is reduced by $0.4{ }^{\circ} \mathrm{C}$ on average because of the aerosol dimming (sulfates essentially), and 

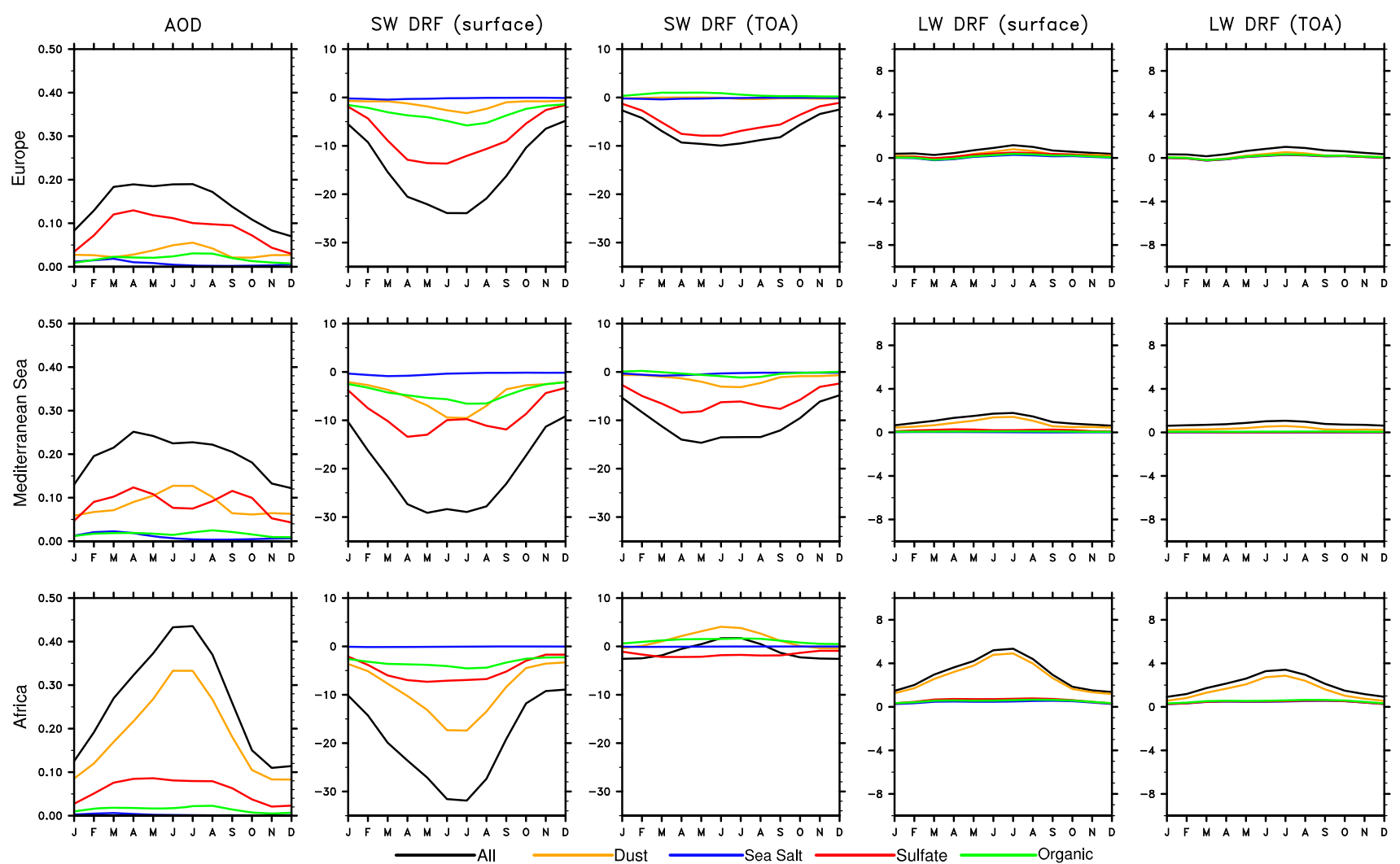

Fig. 9 Monthly average aerosol optical depth and direct radiative forcing $\left(\mathrm{Wm}^{-2}\right)$ in $\mathrm{SW}$ and $\mathrm{LW}$ radiations at the surface and TOA over Europe (top), the Mediterranean Sea (middle) and northern Africa (bottom) for the C-AER simulation ensemble mean and the

different aerosol types. The CI at the level 0.05 calculated from the ensemble spread is for all the regions and months $\pm 0.0 \mathrm{Wm}^{-2}$ ) for all the radiative forcings

up to $1{ }^{\circ} \mathrm{C}$ in summer in eastern and central Europe (see Table 3 for seasonal averages). A similar decrease is observed over northern Africa $\left(-0.5{ }^{\circ} \mathrm{C}\right.$ on average) because of dust aerosols, but contrary to Europe, this effect is also important in winter. These values are important compared to the biases mentioned in the previous section, and their robustness has been proven using the simulation ensembles. Figure 11 indeed only shows significant values at the level 0.05. With regards to SST (Fig. 11b), the decrease is estimated at $0.5^{\circ} \mathrm{C}$ on average over the Mediterranean Sea, and can reach $1{ }^{\circ} \mathrm{C}$ in summer in the Adriatic Sea and near the African coast, which is consistent with the study of Yue et al. (2011) at the global scale. A contrast can also be noticed in winter, spring and autumn between the western and the eastern basins. Moreover, the impact remains high in autumn $\left(-0.5^{\circ} \mathrm{C}\right)$ despite a decrease in the aerosol load. Like $2 \mathrm{~m}$-temperature, the aerosol impact on SST is of the same rough size as the bias in RCMs (e.g. Artale et al. 2010; L'Hévéder et al. 2012).

The modification of SST by aerosols involves changes in the heat budget over the Mediterranean Sea including air-sea fluxes. Figure $11 \mathrm{c}$, d, respectively, present the average seasonal difference in sensible and latent heat loss between C-AER and C-NO. The sensible heat loss has substantially decreased over Europe $\left(-4.7 \mathrm{Wm}^{-2}\right)$ and northern Africa $\left(-8.5 \mathrm{Wm}^{-2}\right)$, especially in summer. This diminution is probably due to decrease in surface temperature. Even if the sensible flux is weaker over ocean than over land surfaces, the Mediterranean Sea is affected by a decrease of about $10 \%$ in sensible heat loss. Moreover, aerosols cause a significant decrease in the latent heat loss over the Mediterranean Sea, reaching $-13.6 \mathrm{Wm}^{-2}$ in summer and $-13.5 \mathrm{Wm}^{-2}$ in autumn. Indeed, because of the decrease in surface temperature, the saturated humidity at the ocean surface also decreases, thus reducing the latent heat flux. Europe is affected by a diminution of evaporation in spring. Once again the aerosol impact on air-sea fluxes shows differences of the same rough size as biases in RCMs (Sanchez-Gomez et al. 2011), highlighting the importance to take them into account to simulate climate over the Mediterranean region.

As a consequence, the total heat budget at the surface between the two simulations has been changed by aerosols (see Table 4). Over northern Africa, the decrease in SW downward radiation is counterbalanced by a decrease in LW up radiation, as well as in sensible heat loss. The total 


\section{(a) - Aerosol semi-direct SW forcing}
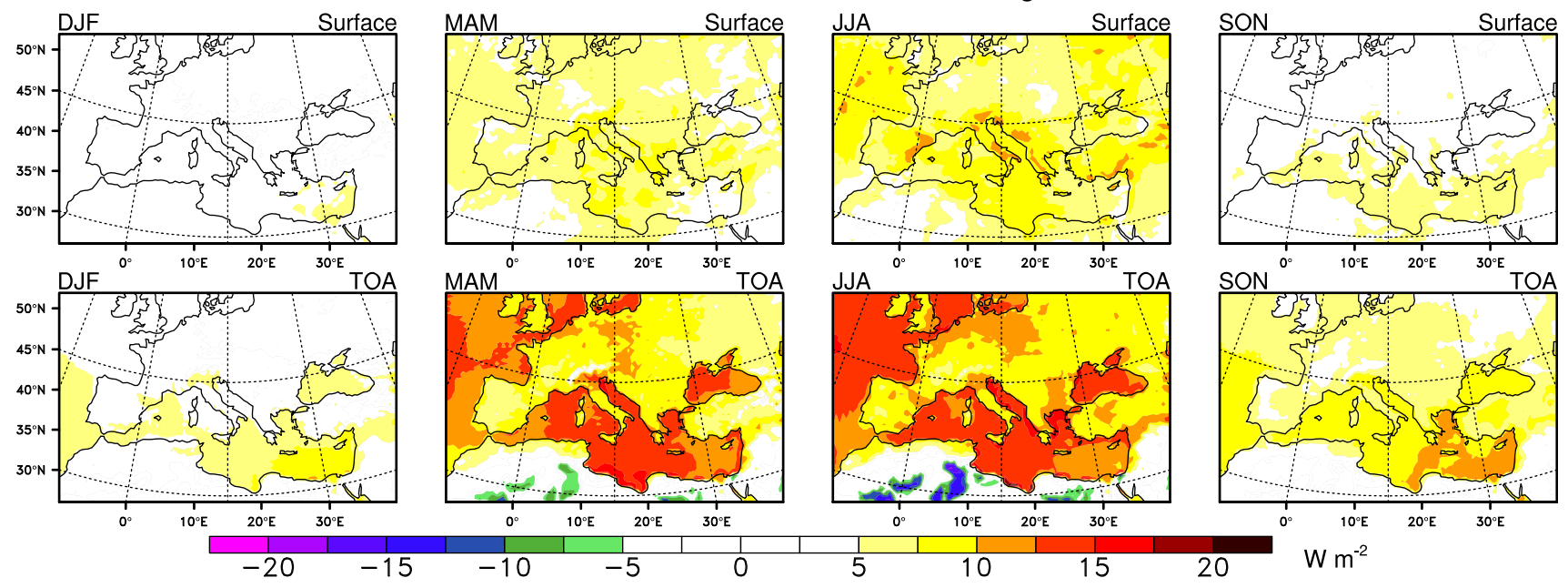

(b) - Aerosol semi-direct LW forcing
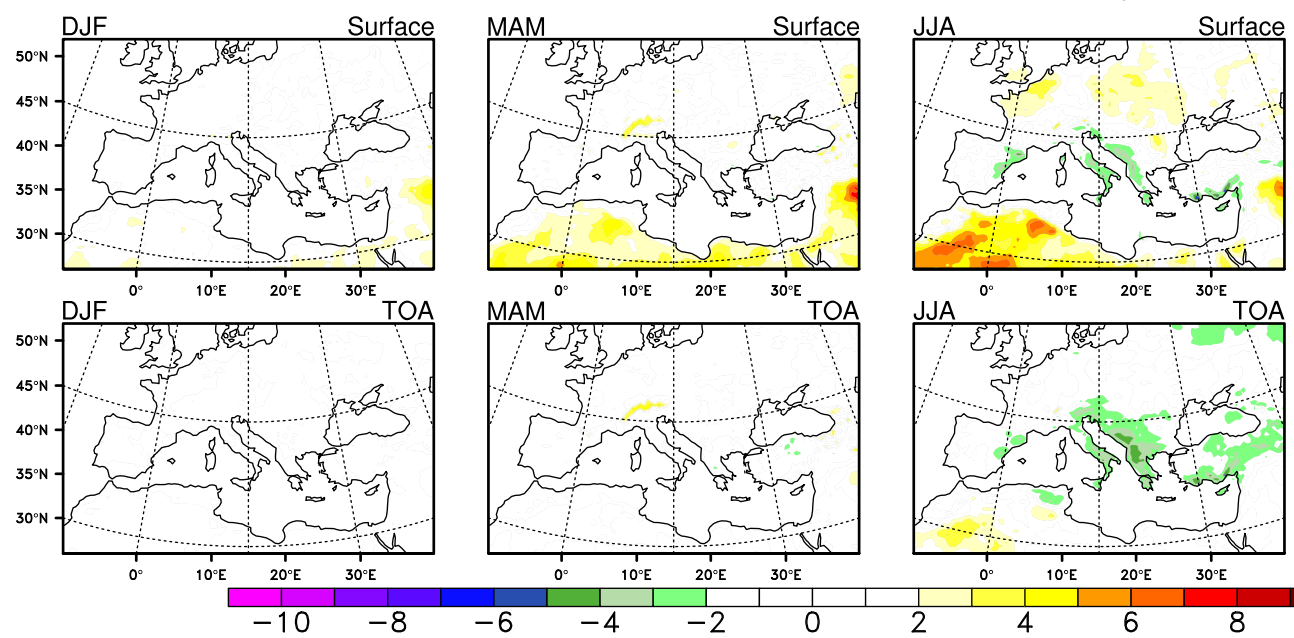

20

$\mathrm{W} \mathrm{m}^{-2}$
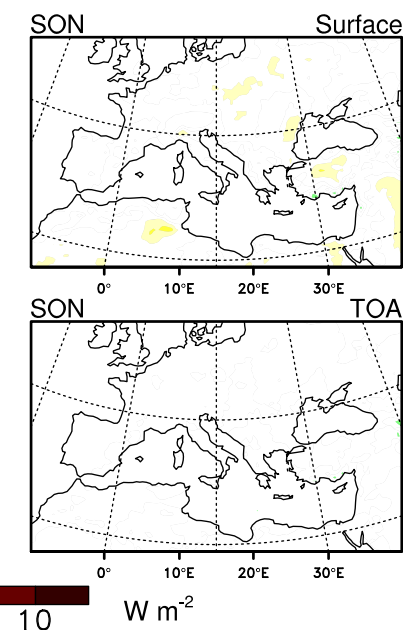

Fig. 10 Average seasonal semi-direct radiative forcing $\left(\mathrm{Wm}^{-2}\right)$ in $\mathrm{SW}(\mathbf{a})$ and $\mathrm{LW}$ (b) radiations at the surface and at TOA for the C-AER simulation ensemble mean. Only significant values at the level 0.05 are plotted

budget difference caused by aerosols, i.e. the residual of the energy balance, is sligthly negative in spring $\left(-0.2 \mathrm{Wm}^{-2}\right)$, and slightly positive in autumn $\left(+0.2 \mathrm{Wm}^{-2}\right)$, resulting in a zero annual effect as expected. The soil's thermal capacity is indeed not high enough to maintain these differences. Over Europe, the decrease in SW downward radiation is counterbalanced by the same fluxes, plus the latent heat loss. This decrease in evaporation causes a positive impact on the heat budget in spring $\left(+0.4 \mathrm{Wm}^{-2}\right)$, for a zero annual effect. Over the Mediterranean Sea, the annual impact is negative $\left(-1.5 \mathrm{Wm}^{-2}\right)$, because the latent heat loss and LW upward flux do not counterbalance totally the SW effect.

As a result of the decrease of the latent heat loss, surface specific humidity also decreases with the presence of aerosols. Figure 11e presents the average seasonal difference of surface specific humidity between C-AER and C-NO. This diminution ranges from $-0.1 \mathrm{~g} / \mathrm{kg}$ in winter to $-0.5 \mathrm{~g} / \mathrm{kg}$ in summer near the western coasts and in the Ionian basin. Coastal land regions are also affected in summer, notably eastern Spain, Tunisia and Italy, indicating probably a reduction of convection because of the increase of atmospheric stability due to the presence of aerosols. Over central Europe, a slight increase in summer can be noted probably due to a modification in atmospheric circulation. In line with this decrease in humidity and increase in stability, the comparison of simulations reveals a decrease of cloud cover (Fig. 11g) with the adding of aerosols, ranging from -1 to $-3 \%$ over the Mediterranean Sea and Europe, in spring and summer, but also in autumn over the sea. Consequently, aerosols also tend to reduce precipitation (Fig. 11f): $-0.2 \mathrm{~mm} /$ day on annual average 


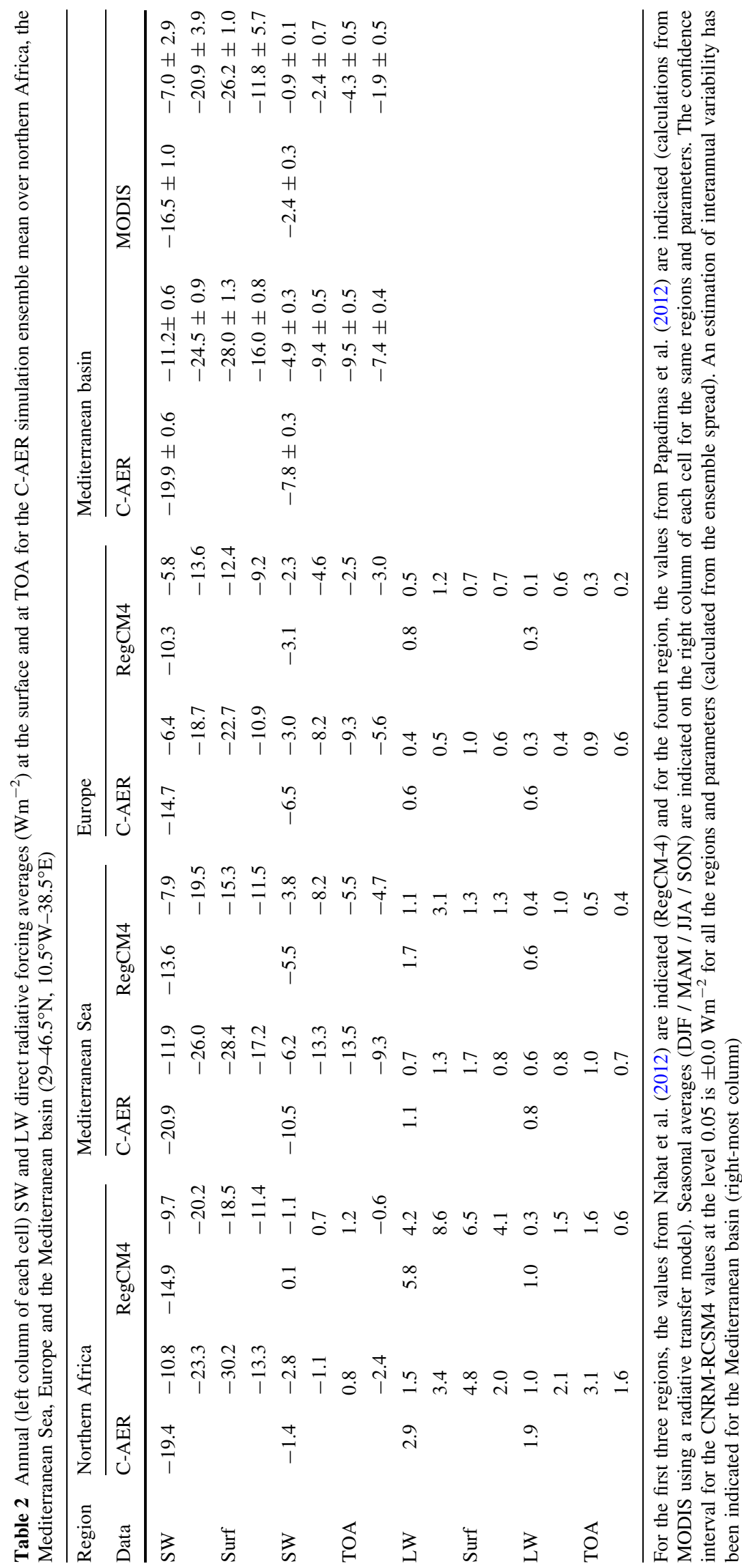


(a)

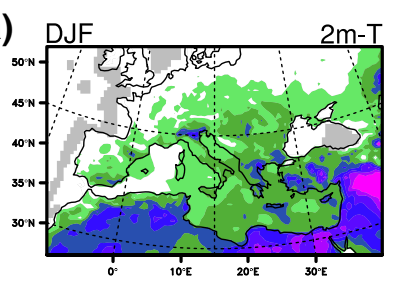

(b)

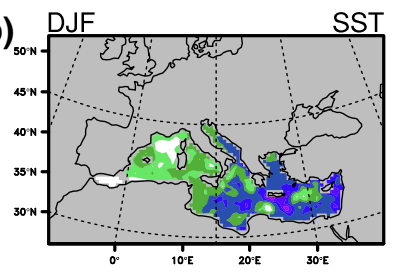

(c)

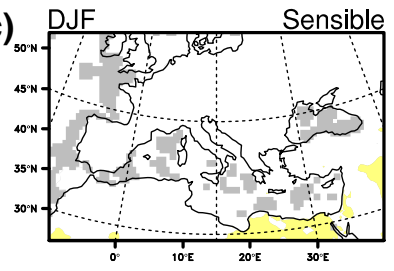

(d)

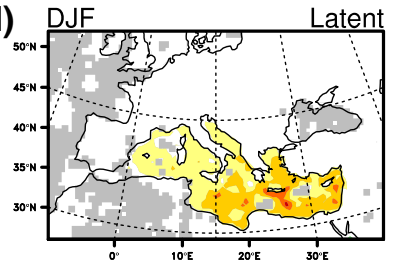

(e)

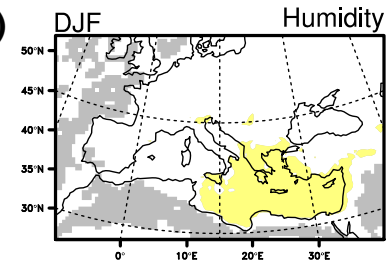

(f)

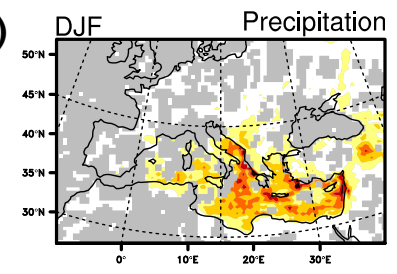

(g)

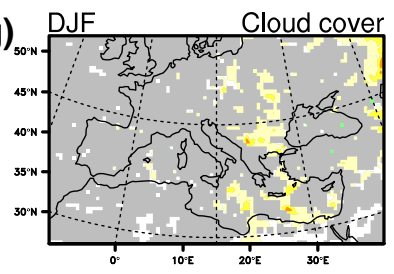

(h)

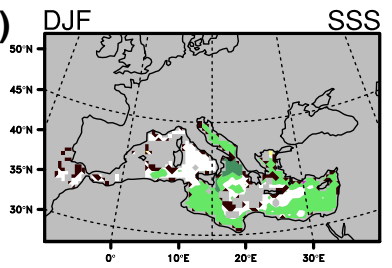

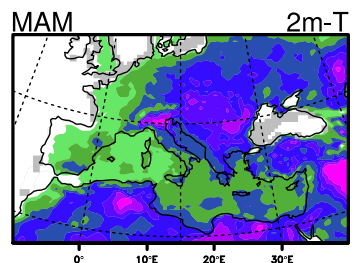
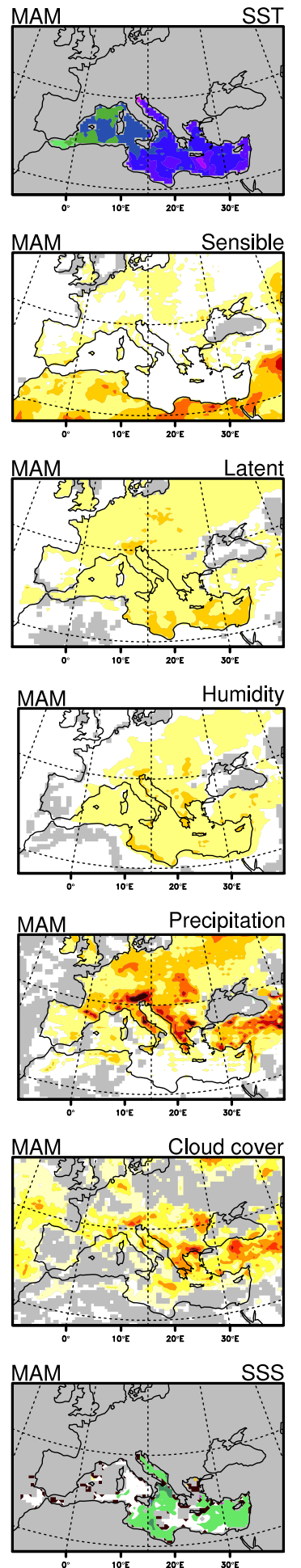
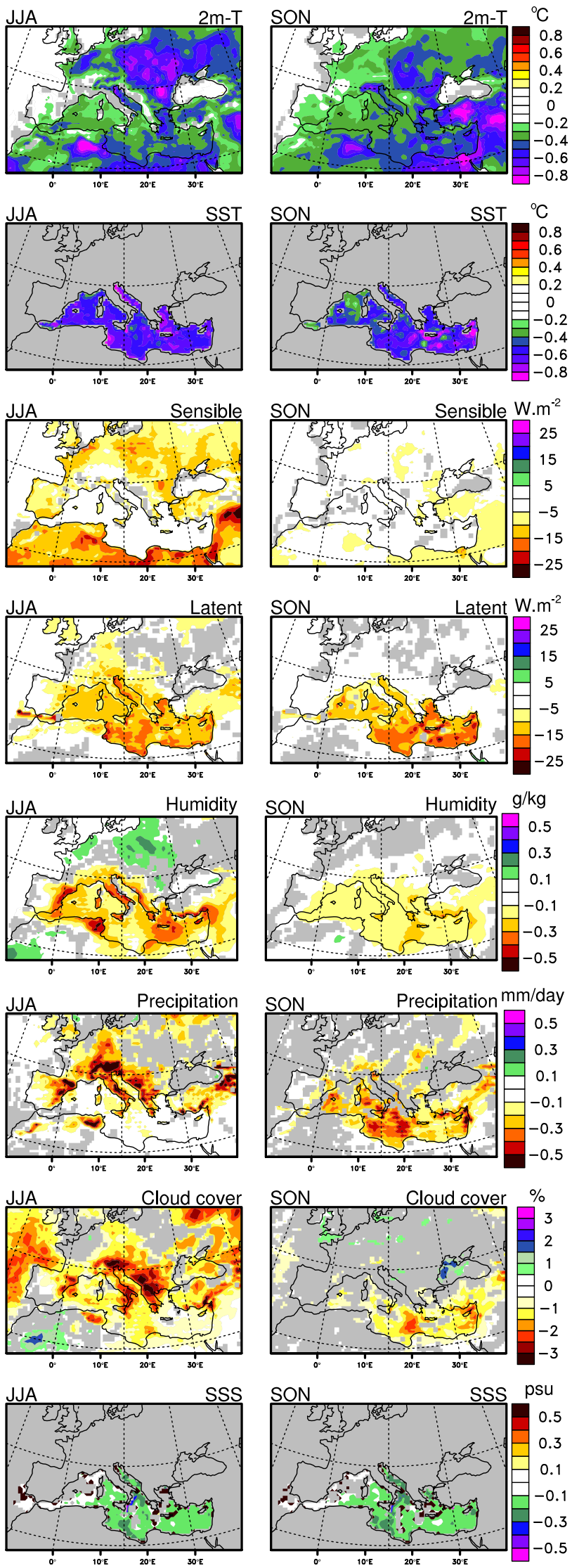
4Fig. 11 Average seasonal differences between the C-AER and the C-NO simulation ensemble means in terms of $2 \mathrm{~m}$-temperature $\left({ }^{\circ} \mathrm{C}\right.$, a), SST $\left({ }^{\circ} \mathrm{C}, \mathbf{b}\right)$, sensible $\left(\mathrm{Wm}^{-2}, \mathbf{c}\right)$ and latent $\left(\mathrm{Wm}^{-2}, \mathbf{d}\right)$ heat loss, surface specific humidity $(\mathrm{g} / \mathrm{kg}$, e), precipitation $(\mathrm{mm} / \mathrm{day}, \mathbf{f})$, cloud cover $(\%, \mathbf{g})$ and SSS (psu, h). Only significant values at the level 0.05 are plotted

Table 3 Annual (left column of each cell) difference between the $\mathrm{C}$-AER and the C-NO simulation ensemble means in terms of $2 \mathrm{~m}-$ temperature $\left({ }^{\circ} \mathrm{C}\right)$ and precipitation $(\mathrm{mm} /$ day) over northern Africa, the Mediterranean Sea and Europe, as well as SST $\left({ }^{\circ} \mathrm{C}\right)$ over the Mediterranean Sea

\begin{tabular}{lcccccc}
\hline Parameter & \multicolumn{2}{l}{$\begin{array}{l}\text { Northern } \\
\text { Africa }\end{array}$} & \multicolumn{3}{l}{ Mediterranean } & Europe \\
& Sea & & & \\
\hline 2m-temperature & -0.5 & -0.5 & -0.4 & -0.3 & -0.4 & -0.2 \\
& & -0.5 & & -0.4 & -0.4 \\
& & -0.4 & & -0.4 & -0.4 \\
SST & & -0.5 & & -0.4 & & -0.4 \\
& & & -0.5 & -0.4 & & \\
& & & & -0.5 & & \\
Precipitation & & & & -0.6 & & \\
& & & & -0.5 & & \\
& & & & & & \\
& & 0.0 & -0.2 & -0.2 & -0.1 & -0.1 \\
& & & -0.1 & & -0.2 \\
& & 0.1 & & -0.1 & -0.2 \\
& 0.0 & & -0.2 & -0.1 \\
\hline
\end{tabular}

Seasonal averages (DJF / MAM/JJA/SON) are indicated on the right column of each cell for the same regions and parameters. The confidence interval at the level 0.05 calculated from the ensemble spread is for all the regions and seasons $\pm 0.0{ }^{\circ} \mathrm{C}$ for $2 \mathrm{~m}$ and SST, and $\pm 0.0 \mathrm{~mm} /$ day for precipitation

over the Mediterranean Sea and $-0.1 \mathrm{~mm} /$ day over Europe, and up to $-0.5 \mathrm{~mm} /$ day in Italy and Croatia in spring (seasonal values are recalled in Table 3). These modifications of precipitation and evaporation (also reduced by aerosols, figure not shown), lead to a decrease of sea surface salinity (SSS, Fig. 11h). Indeed, evaporation is strongly reduced by aerosols over the Mediterranean Sea $(-0.37 \mathrm{~mm} /$ day $)$, which prevails over the reduction in precipitation $(-0.15 \mathrm{~mm} /$ day $)$. The total water budget of the Mediterranean Sea could also be affected by changes in river discharges caused by changes in precipitation over land, but runoffs only decrease by $-0.01 \mathrm{~mm} /$ day in C-AER. Consequently, SSS is found to decrease by -0.10 psu on average under the effects of aerosols, with a maximum in autumn $(-0.12$ psu, Fig. $11 \mathrm{~h})$. The contrast between the aerosol impact on SSS in north-western and south-eastern Mediterranean is similar to the impact on latent heat fluxes.

To summarize, the direct effect of aerosols is responsible for a significant decrease in surface temperature over Europe and northern Africa, as well as a decrease in SST over the Mediterranean Sea. It can also be seen as a reduction of the activity of the hydrological cycle with a decrease in precipitation, cloud cover and humidity, which will be discussed in details in the next section. The robustness of these results has been confirmed by the simulation ensembles.

\subsection{Impact of ocean-atmosphere coupling on the aerosol climatic response}

Until now the present study has used simulations from a fully coupled modeling system, including atmosphere, ocean, land surface and rivers. In this section and in order to understand the role of ocean-atmosphere coupling, simulations have been carried out with the atmosphere model ALADIN only (including the land surface scheme). Figure 12 presents the average summer difference beween the fully coupled simulation ensemble mean differences (C-AER-C-NO) and the same differences in forced simulations (F-AER-F-NO), for different parameters : semidirect SW (a) and LW (b) aerosol radiative forcings, $2 \mathrm{~m}$ temperature (c), surface specific humidity (d), latent (e) and sensible (f) heat losses, precipitation (g) and cloud cover (h). The summer season has been chosen because it is the period of the year when the aerosol forcing is maximal (see Fig. 11).

As in coupled simulations, aerosols scatter and absorb the incident radiation, resulting in a decrease in surface SW radiation. The aerosol DRF is consequently similar in coupled and forced simulations (figure not shown). On the contrary the semi-direct aerosol effect shows significant differences (Fig. 12a and b): the SW semi-direct radiative forcing is higher up to $+4 \mathrm{Wm}^{-2}$ in coupled simulations, whereas the semi-direct LW effect is higher in coupled simulations in coastal regions of the Mediterranean Sea Fig. 12b. SW and LW radiation has actually been modified in the response in forced simulations because of changes of cloud cover (h) and humidity (d) over the sea essentially, and regions under maritime influence. This could imply aerosols have less impact on clouds in forced simulations over the Mediterranean Sea and its surroundings.

As SSTs are prescribed, no impact of aerosols has been noticed in 2m-temperature over the Mediterranean Sea in forced simulations, as Fig. 12c shows a decrease in temperature similar to the coupled simulations. Over land surfaces, the decrease is generally of the same intensity as in coupled simulations, except over coastal regions (e.g. northern Egypt, Italy, eastern Spain, ...) where the temperature decrease is less important without the oceanatmosphere coupling. This is due to maritime advection that can bring cooler air in coupled simulations, where aerosols have been able to decrease SST. As SSTs are prescribed, the decrease of the latent heat loss with aerosols (e) is weaker in forced simulations, and almost equal to 
Table 4 Annual (left column of each cell) heat budget difference $\left(\mathrm{Wm}^{-2}\right)$ at the surface between the C-AER and the C-NO simulation ensemble means over northern Africa, the Mediterranean Sea and Europe

\begin{tabular}{|c|c|c|c|c|c|c|}
\hline \multirow{2}{*}{$\frac{\mathrm{DRF}}{\text { SW down surface }}$} & \multicolumn{2}{|l|}{ Northern Africa } & \multicolumn{2}{|c|}{ Mediterranean Sea } & \multicolumn{2}{|l|}{ Europe } \\
\hline & $-20.7 \pm 0.0$ & $\begin{array}{l}-9.8 \pm 0.0 \\
-25.7 \pm 0.1 \\
-34.9 \pm 0.1 \\
-12.6 \pm 0.1\end{array}$ & $-16.2 \pm 0.0$ & $\begin{array}{l}-8.9 \pm 0.1 \\
-21.1 \pm 0.2 \\
-22.3 \pm 0.1 \\
-12.6 \pm 0.1\end{array}$ & $-11.7 \pm 0.2$ & $\begin{array}{l}-4.9 \pm 0.0 \\
-15.2 \pm 0.2 \\
-18.5 \pm 0.4 \\
-8.3 \pm 0.2\end{array}$ \\
\hline LW down surface & $-0.2 \pm 0.1$ & $\begin{array}{l}-0.4 \pm 0.0 \\
0.1 \pm 0.1 \\
0.6 \pm 0.1 \\
-0.9 \pm 0.1\end{array}$ & $-1.8 \pm 0.1$ & $\begin{array}{l}-1.1 \pm 0.1 \\
-1.5 \pm 0.1 \\
-2.3 \pm 0.2 \\
-2.5 \pm 0.1\end{array}$ & $-1.2 \pm 0.0$ & $\begin{array}{l}-0.8 \pm 0.1 \\
-1.7 \pm 0.1 \\
-1.4 \pm 0.0 \\
-0.9 \pm 0.1\end{array}$ \\
\hline SW up surface (loss) & $-5.9 \pm 0.0$ & $\begin{array}{l}-2.8 \pm 0.0 \\
-7.4 \pm 0.0 \\
-10.0 \pm 0.0 \\
-3.6 \pm 0.0\end{array}$ & $-1.1 \pm 0.0$ & $\begin{array}{l}-0.6 \pm 0.0 \\
-1.4 \pm 0.0 \\
-1.5 \pm 0.0 \\
-0.8 \pm 0.0\end{array}$ & $-2.0 \pm 0.0$ & $\begin{array}{l}-1.0 \pm 0.0 \\
-2.5 \pm 0.0 \\
-3.1 \pm 0.1 \\
-1.4 \pm 0.0\end{array}$ \\
\hline LW up surface (loss) & $-5.0 \pm 0.1$ & $\begin{array}{l}-3.2 \pm 0.0 \\
-5.8 \pm 0.0 \\
-7.0 \pm 0.1 \\
-4.1 \pm 0.1\end{array}$ & $-2.9 \pm 0.0$ & $\begin{array}{l}-2.0 \pm 0.1 \\
-2.8 \pm 0.0 \\
-3.6 \pm 0.1 \\
-3.1 \pm 0.1\end{array}$ & $-2.4 \pm 0.1$ & $\begin{array}{l}-1.3 \pm 0.0 \\
-2.8 \pm 0.1 \\
-3.3 \pm 0.3 \\
-2.2 \pm 0.1\end{array}$ \\
\hline Latent heat (loss) & $-1.4 \pm 0.0$ & $\begin{array}{l}-0.5 \pm 0.0 \\
-1.4 \pm 0.0 \\
-2.6 \pm 0.0 \\
-1.1 \pm 0.1\end{array}$ & $-11.0 \pm 0.1$ & $\begin{array}{l}-8.8 \pm 0.2 \\
-8.1 \pm 0.1 \\
-13.6 \pm 0.0 \\
-13.5 \pm 0.2\end{array}$ & $-3.9 \pm 0.1$ & $\begin{array}{l}-1.5 \pm 0.0 \\
-6.9 \pm 0.1 \\
-5.0 \pm 0.4 \\
-2.2 \pm 0.1\end{array}$ \\
\hline Sensible heat (loss) & $-8.5 \pm 0.0$ & $\begin{array}{l}-3.6 \pm 0.0 \\
-10.8 \pm 0.0 \\
-14.6 \pm 0.0 \\
-5.0 \pm 0.0\end{array}$ & $-1.7 \pm 0.0$ & $\begin{array}{l}-1.7 \pm 0.0 \\
-1.7 \pm 0.0 \\
-1.7 \pm 0.0 \\
-1.7 \pm 0.1\end{array}$ & $-4.7 \pm 0.1$ & $\begin{array}{l}-1.4 \pm 0.0 \\
-5.1 \pm 0.1 \\
-8.7 \pm 0.5 \\
-3.4 \pm 0.1\end{array}$ \\
\hline Total heat budget & $0.0 \pm 0.0$ & $\begin{array}{l}0.0 \pm 0.0 \\
-0.2 \pm 0.0 \\
0.0 \pm 0.0 \\
0.2 \pm 0.0\end{array}$ & $-1.5 \pm 0.1$ & $\begin{array}{l}3.1 \pm 0.0 \\
-8.5 \pm 0.2 \\
-4.4 \pm 0.1 \\
4.0 \pm 0.3\end{array}$ & $0.0 \pm 0.0$ & $\begin{array}{l}-0.5 \pm 0.0 \\
0.4 \pm 0.0 \\
0.1 \pm 0.0 \\
0.1 \pm 0.0\end{array}$ \\
\hline
\end{tabular}

Parameters are the downward and upward SW and LW radiations at the surface as well as the latent and sensible heat losses. All fluxes are counted positively, and total $=\mathrm{SW}_{d}+\mathrm{LW}_{d}-\mathrm{SW}_{u}-\mathrm{LW}_{u}-$ latent $_{\text {loss }}-$ sensible $_{\text {loss }}$. Seasonal averages (DJF / MAM / JJA / SON) are indicated on the right column of each cell for the same regions and parameters. The confidence interval at the level 0.05 is indicated (calculated from the ensemble spread)

zero over the sea. As a consequence, surface specific humidity aerosol effect difference between coupled and forced simulations (Fig. 12d) is negative over the Mediterranean Sea, indicating that there is almost no humidity decrease without ocean-atmosphere coupling. Coastal regions such as the North-African coast, eastern Spain and Italy are also affected by this decrease in humidity in coupled simulations only. With regards to precipitation $(\mathrm{g})$, the drying over these coastal regions (Spain, Tunisia, Sicilia) is consequently reinforced in coupled simulations. In forced simulations, the reduction of the impact on the hydrological caused by the prescription of SSTs alleviates this drying effect. The same phenomenon can be noted for cloud cover (h).

To conclude, this comparison between forced and coupled simulations highlights the importance of using a fully coupled RCSM to investigate the response of Mediterranean climate to aerosol direct and semi-direct SW-LW radiative forcing. Otherwise the aerosol effect could be underestimated as shown in previous studies (e.g. Yue et al. 2011).

\subsection{Aerosol effects on the Mediterranean Sea}

The ocean-atmosphere coupling also enables to study the effect of aerosols on the Mediterranean Sea. As shown previously, aerosols lead to a decrease of SST and an increase of SSS, resulting in changes in water density and water circulation. The prevailing effect has been found to be an increase of sea surface density, potentially favouring ocean deep convection and reinforcing the regional thermohaline circulation. Figure 13 presents the volume of 


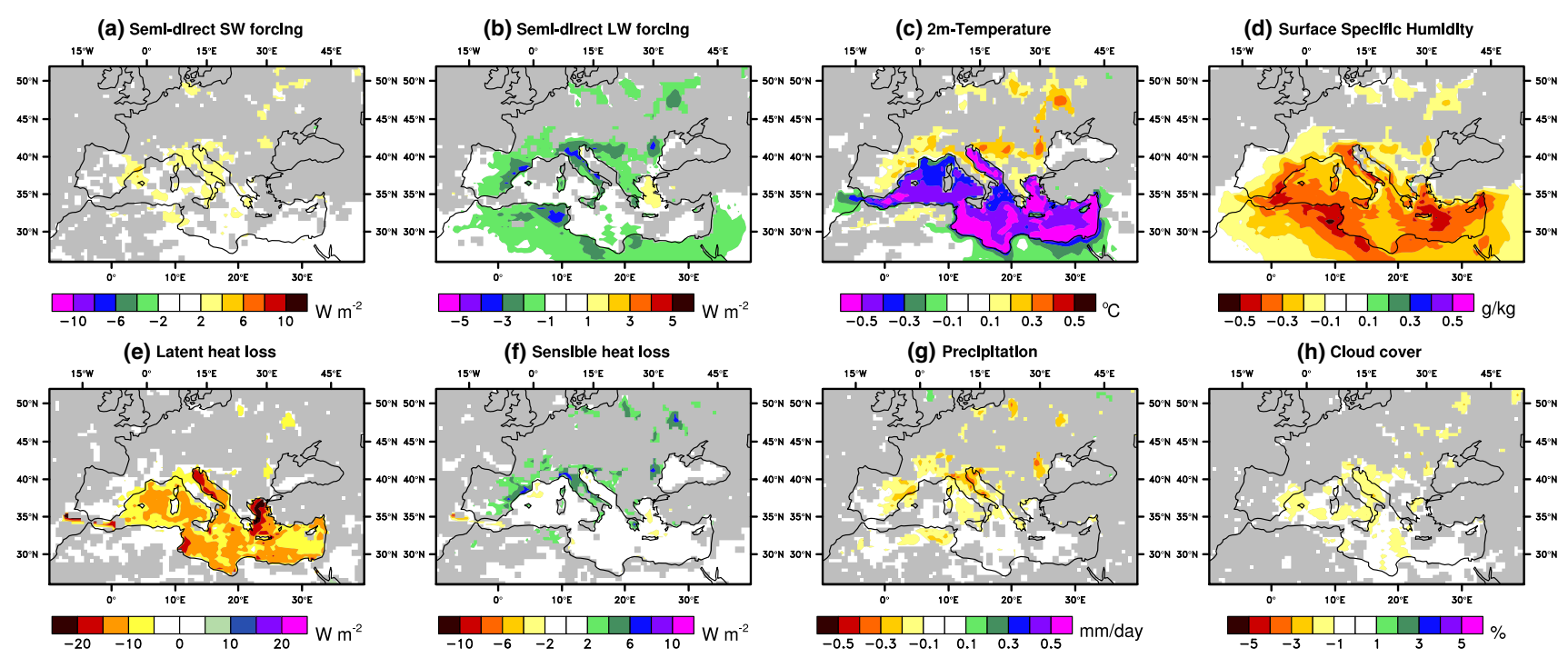

Fig. 12 Average summer differences in the aerosol effect between coupled and forced simulation ensemble means: (C-AER-C-NO) (F-AER-F-NO); in terms of semi-direct SW $\left(\mathrm{Wm}^{-2}\right.$, a) and LW $\left(\mathrm{Wm}^{-2}\right.$, b) forcings, $2 \mathrm{~m}$-temperature $\left({ }^{\circ} \mathrm{C}, \mathbf{c}\right)$, surface specific

water with density higher than $29.1 \mathrm{~kg} / \mathrm{m}^{3}$ in the Gulf of Lions (a) and $29.3 \mathrm{~kg} / \mathrm{m}^{3}$ in the Adriatic Sea (b). In these two basins, an increase of the volume of dense water is noticed in C-AER in winter, when deep water is formed. In particular, during the winter 2004-2005, known to be a period of strong ocean convection in the Gulf of Lions (Schroeder et al. 2008), the formation of deep water has increased from 1.4 Sv in C-NO to $2.2 \mathrm{~Sv}$ in C-AER. The confidence interval calculated from the ensemble spread shows the robustness of these results. Besides, this amplification of oceanic convection with aerosols can also be seen in the meridional (Fig. 13c, d) and zonal (Fig. $13 \mathrm{e}-\mathrm{f}$ ) overturning streamfunctions for the C-AER simulation and the C-AER-C-NO difference. These functions are calculated from the vertical integration of the meridional (resp. zonal) current velocities averaged along the longitudes (resp. latitudes), as in Somot et al. (2006), thus showing the main circulations in a $\mathrm{X}-\mathrm{Z}$ (resp. Y-z) plan. The increase in the deep water formation in the Adriatic Sea in C-AER leads to an increase in the outflow at the Otranto Strait, with dense water reaching higher depths in the Northern Ionian Sea in C-AER (Fig. 13c, d). With regards to the zonal overturning streamfunction (Fig. 13e, f), the circulation of the surface Atlantic water eastward as well as the westward path of the Levantine intermediate water in the under layer are simulated both in C-AER and C-NO. However, an amplification of the formation of deep water either coming from the Adriatic Sea $\left(16-20^{\circ} \mathrm{E}\right.$ below $2,000 \mathrm{~m}$ ) or coming from the Aegean Sea $\left(20-25^{\circ} \mathrm{E}\right)$ is found in C-AER (Fig. 13f), thus reinforcing the thermohaline circulation. To summarize, aerosols tend to densify humidity $(\mathrm{g} / \mathrm{kg}, \mathbf{d})$, latent (e) and sensible (f) heat loss $\left(\mathrm{Wm}^{-2}\right)$, precipitation $(\mathrm{mm} /$ day, $\mathbf{g})$ and cloud cover $(\%, \mathbf{h})$. Only significant values at the level 0.05 are plotted

surface water, thus amplifying ocean convection and deep water formation in winter.

Due to the complexity of aerosol-climate processes involved over the Mediterranean, an elaborated study is presented in the following section using two case studies that illustrate some important processes and possible positive feedbacks in the aerosol-atmosphere-ocean-land system.

\section{Process studies}

\subsection{Dust effect in the eastern basin}

As mentioned previously, dust aerosols are generally transported from the Libyan desert to the Mediterranean from spring to autumn. These dust outbreaks have significant effects on the vertical profiles of different parameters such as temperature and humidity (e.g. Miller and Tegen 1998). Figure 14 presents the aerosol effects over the eastern Mediterranean during June 2007. This month was indeed submitted to larger than usual dust loads over the Mediterranean Sea (0.14 for AOD at $550 \mathrm{~nm}$ over MEDE) and northeastern Africa (0.32 over AFRE), as shown in Fig. 14 (b, top left). Figure 14a presents the vertical profile differences for coupled and forced simulations in temperature, humidity and geopotential, as well as the aerosol vertical distribution, over the eastern Mediterranean Sea (MEDE) and northeastern Africa (AFRE).

Over AFRE, near-surface temperature profiles confirm the cooling due to the absorption and scattering of the 

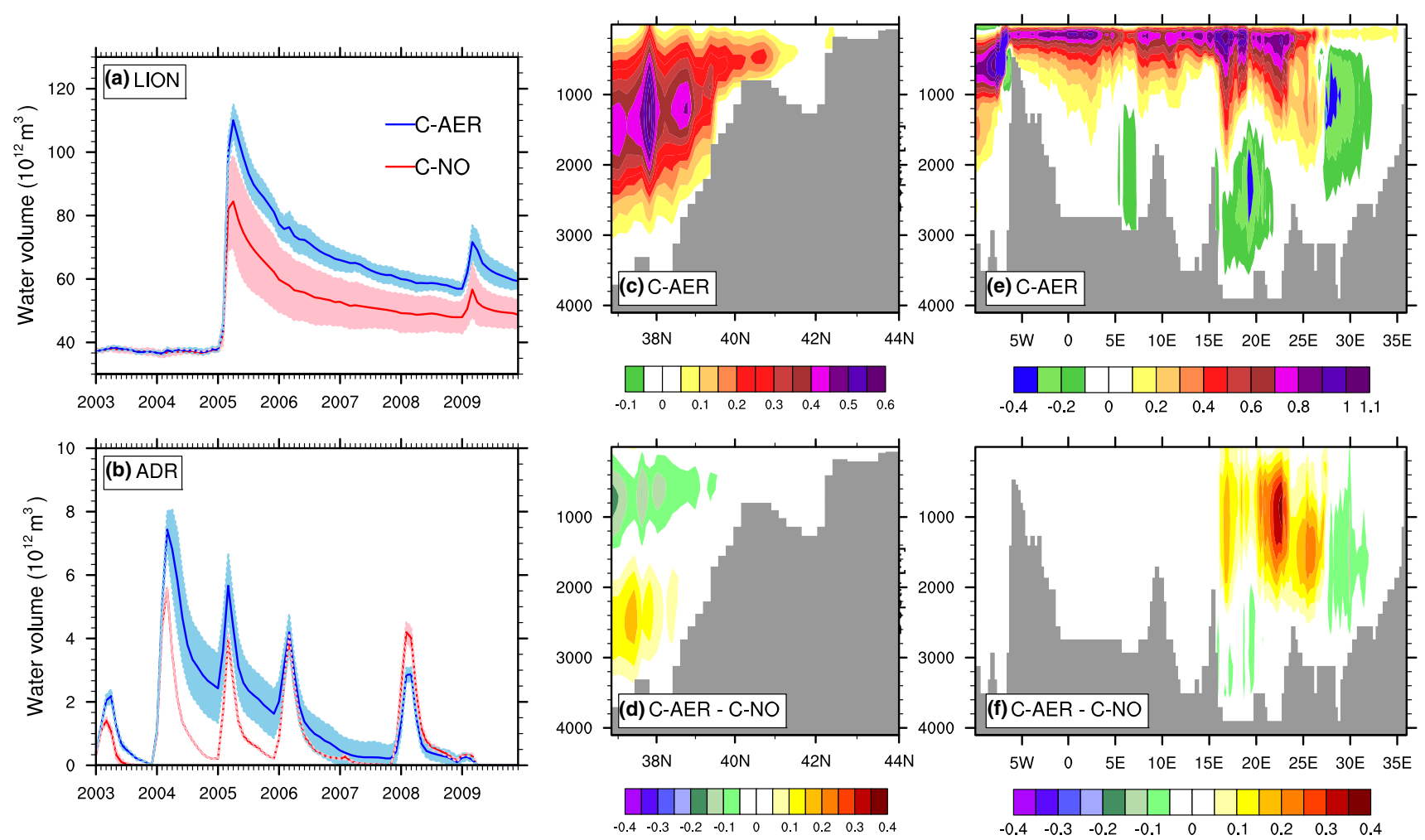

Fig. 13 Aerosol effects on the Mediterranean Sea. a Monthly water volume $\left(10^{12} \mathrm{~m}^{3}\right)$ with density higher than $29.1 \mathrm{~kg} / \mathrm{m}^{3}$ in the Gulf of Lions for the C-AER (blue) and C-NO (red) simulations. The confidence interval at the level 0.05 based on the ensemble spread has been added around the curves. b Same as (a) but for monthly water volume $\left(10^{12} \mathrm{~m}^{3}\right)$ with density higher than $29.3 \mathrm{~kg} / \mathrm{m}^{3}$ in the Adriatic

incoming solar radiation thus prevented from reaching surface. The decrease in temperature due to aerosols reaches $-0.3{ }^{\circ} \mathrm{C}$ in forced simulations and $-0.4{ }^{\circ} \mathrm{C}$ in coupled simulations. These profiles also enable us to highlight the warming between 600 and $950 \mathrm{hPa}$ (between +0.3 and $+0.4{ }^{\circ} \mathrm{C}$ ), due to the $\mathrm{SW}$ absorption by dust particles present at the same heights. The simulation ensembles show a weaker uncertainty on the cooling in surface temperature than in the intensity of the warming in the mid-troposphere. This warming can also be noticed over the Mediterranean Sea (between +0.5 and $+0.7^{\circ} \mathrm{C}$ ). However, the decrease in surface air temperature is only present in coupled simulations $\left(-0.3{ }^{\circ} \mathrm{C}\right)$, as SST can be modified by dust aerosols.

As a result, the reduction in near-surface temperature has lead to a decrease in latent heat loss over the Mediterranean Sea (figure not shown), and thus to specific humidity in the lower troposphere (blue curves in Fig. 14a, up to $-0.8 \mathrm{~g} / \mathrm{kg}$ at 1,000 hPa). Over the continent (AFRE), this decrease in humidity is also more important in coupled simulations, reaching $-0.4 \mathrm{~g} / \mathrm{kg}$ between $925 \mathrm{hPa}$ and the surface, than in forced simulations $(-0.06 \mathrm{~g} / \mathrm{kg})$. Figure 14 (b, top right)
Sea. c Meridional overturning streamfunction in the Adriatic Sea for the C-AER ensemble mean over the period 2003-2009. d Same as (c) but for the difference C-AER-C-NO. e Zonal overturning streamfunction for the C-AER ensemble mean over the period 2003-2009. f Same as (e) but for the difference C-AER - C-NO

shows that the eastern Mediterranean Sea is affected by northerly winds in summer, advecting maritime air to the African continent. As a result, this decrease in humidity has been advected over northeastern Africa. Cooler air is also advected at the surface, reinforcing the decrease in nearsurface temperature due to the direct aerosol effect, which explains the differences mentioned below between coupled and forced simulations in the aerosol impact.

These changes in temperature, humidity and air-sea fluxes also affect the atmospheric circulation. Figure 14 (b, bottom) presents the aerosol impact in coupled simulations on wind and geopotential at the surface (left) and at $850 \mathrm{hPa}$ (right). Aerosols tend to stabilize the atmosphere above $900 \mathrm{hPa}$ over the eastern Mediterranean Sea and $850 \mathrm{hPa}$ over notheastern Africa, generating an anticyclonic wind anomaly. At the surface, the difference between C-AER and C-NO shows a decrease in sea level pressure, and a northly wind anomaly over the eastern basin, reinforcing the average northly wind over this region, and its consequences for the aerosol impact. As a consequence, this first case study clearly illustrates a positive feedback between dust aerosols, atmosphere, and 
(a) - Vertical profiles
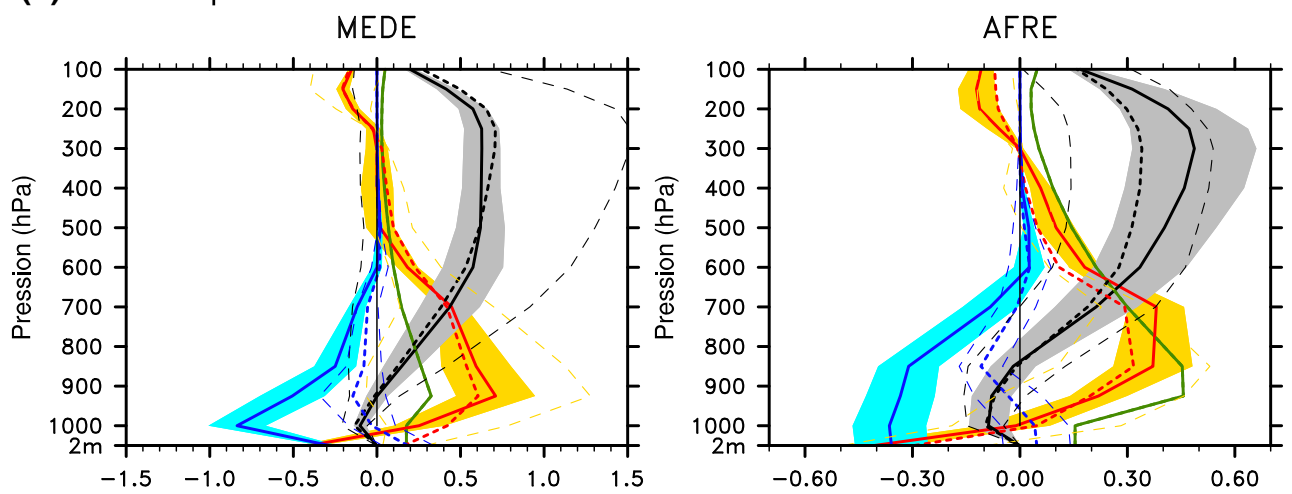

(b) - Aerosols and atmospheric circulation
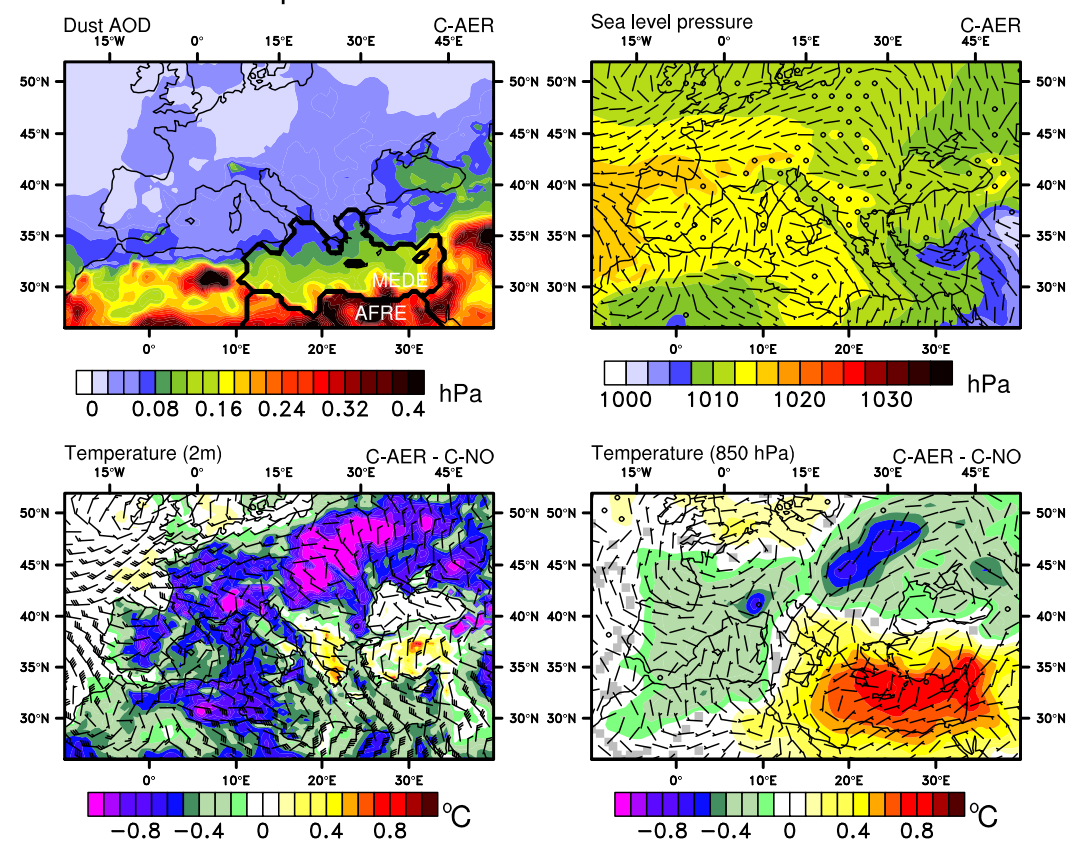

Fig. 14 Average vertical profiles (a) and atmospheric circulation (b) over the Mediterranean in June 2007. Profiles are calculated over Northeastern Africa (AFRE) and the eastern Mediterranean Sea (MEDE) representing the difference between C-AER and C-NO for temperature $\left({ }^{\circ} \mathrm{C}\right.$, red $)$, geopotential $\left(10^{2} \mathrm{gpm}\right.$, black $)$, specific humidity $(\mathrm{g} / \mathrm{kg}$, blue $)$ and extinction coefficient $\left(\mathrm{km}^{-1}\right.$, green $)$. The same parameters are indicated in dotted lines for the difference between F-AER and F-NO. The confidence interval at the level 0.05

(calculated from the 6-member ensembles) is indicated for each parameter in color for C-AER - C-NO, and in dashed lines for F-AER-F-NO. Atmospheric circulation (b) is represented with AOD (top left), sea level pressure ( $\mathrm{hPa}$, color $)$ and surface wind barbs $(\mathrm{m} / \mathrm{s})$ for the C-AER simulation (top right), and temperature $\left({ }^{\circ} \mathrm{C}\right.$, color $)$ and surface wind $(10 \mathrm{~m} / \mathrm{s}$, barbs) difference at the surface (bottom left) and at $850 \mathrm{hPa}$ (bottom right). Only significant values at the level 0.05 are plotted

ocean, which is stronger in fully coupled simulations than in atmosphere-only ones.

\subsection{Aerosol effect during a European heat wave}

The second aerosol event studied in this work occurs in July 2006, when western Europe was affected by a heat wave (Rebetez et al. 2008) with temperature anomalies ranging from 4 to $6{ }^{\circ} \mathrm{C}$ in a large zone (France, Benelux, Poland, Switzerland, Germany). The synoptic situation

was characterized by high geopotentials over Maghreb, generating a powerful ridge over western Europe, and advecting dry air masses over these regions. The monthly average geopotential and wind at $700 \mathrm{hPa}$ simulated in C-AER are presented in Fig. 16b. High geopotentials are reproduced by the model, showing this southwesterly flow from Morocco to Germany. Compared to the average 2003-2009, surface temperature in July 2006 is higher by $2.9 \pm 0.1{ }^{\circ} \mathrm{C}$ in C-AER over EURS, showing the ability of CNRM-RCSM4 to reproduce this heat wave. 
This month was also characterized by high dust loads, as shown in Fig. 15, notably over Spain and northwestern Africa. In parallel, sulfate aerosols were prevailing over France and western Europe. Total AOD at $550 \mathrm{~nm}$ reaches 0.47 in northwestern Africa (AFRW), 0.23 over the western Mediterranean Sea (MEDW) and 0.22 in southwestern Europe (EURS). These three zones used in this section have been defined in Fig. 2.

Figure 16 presents the vertical profiles (a) of the aerosol impact on temperature, geopotential and specific humidity over these three zones for coupled and forced simulations, as well as the aerosol impact on the atmospheric circulation at $700 \mathrm{hPa}$ (b) and temperature (c). As in the first case over the eastern Mediterranean, the direct effect of dust aerosols causes a cooling at the surface over northwestern Africa $\left(-0.2^{\circ} \mathrm{C}\right)$, and a decrease in SST and near-surface air temperature over the western Mediterranean Sea in the fully coupled simulations. Between 600 and $1000 \mathrm{hPa}$, the absorption of solar radiation by dust aerosols tends to warm (on average $+0.8{ }^{\circ} \mathrm{C}$, see the increase in temperature at $700 \mathrm{hPa}$, Fig. 16c) and stabilize the atmosphere (see the geopotential profile, Fig. 16 a). This phenomenon increases the geopotential at $700 \mathrm{hPa}$ (b), thus reinforcing the ridge over western Europe. As a consequence, the southwesterly flow responsible for dry and warm air masses advection is reinforced in C-AER compared to $\mathrm{C}-\mathrm{NO}$, and can also contribute to the increase in temperature in the mid-troposphere, but also at the surface over southwestern Europe. Figure 16 (c, right) shows an increase in $2 \mathrm{~m}$-temperature of $0.5{ }^{\circ} \mathrm{C}$ on average over EURS, and up to $1.2^{\circ} \mathrm{C}$ locally in southeastern France and in Italy. The warming can also be due to the presence of dust aerosols themselves over this region, and dynamics is probably not the only explanation. At the surface, this study underlines that, in this specific case, the dust dynamic effects (here, increase of the advection of dry air masses) should certainly exceed the cooling effect over land due to the dust surface forcing.

Over the Mediterranean Sea, dust aerosols also prevent the radiation from reaching the surface, thus decreasing SST and latent heat loss (figure not shown). As a consequence, Fig. 16a shows a decrease in specific humidity in the lower troposphere (up to $-1.1 \mathrm{~g} / \mathrm{kg}$ ), making the air even drier. This effect is attenuated in the atmosphere-only simulations because of the prescription of SST. This drying caused by aerosols is another factor tending to reinforce the ridge over western Europe. This aerosol effect on oceanatmosphere fluxes explains why we have observed a more important warming due to aerosols in the coupled simulations than in the forced simulations (see the profiles over EURS and MEDW in Fig. 16a).

One important finding of this case is that, in some situations like this heat wave over Europe, the presence of dust particles associated with the ridge has lead to a positive feedback consisting in a reinforcement of the ridge and an extra warming in the whole troposphere, that exceeds the cooling effect due to the dust dimming. As a result, July 2006 has been noticed to be $2.9 \pm 0.1^{\circ} \mathrm{C}$ higher than average July in the C-AER simulations, and only $2.4 \pm$ $0.1^{\circ} \mathrm{C}$ higher in the $\mathrm{C}-\mathrm{NO}$ simulation, indicating aerosols are responsible for $0.5^{\circ} \mathrm{C}$ of this heat wave, namely about $15 \%$. The atmosphere-ocean coupling also enables to take into account the drying of the lower atmosphere due to the decrease in SST, underlying the importance of taking into account the effect of particles on ocean-atmosphere fluxes and SST. It should also be noted that these results cannot be attributed to the RCM internal variability as they have been confirmed by the 6-member ensembles used here. Finally, this study also highlights that the radiative effect of dust needs to be treated in forecast models for improving the simulations of meteorological fields in such specific cases.

\section{Conclusion}

The Mediterranean region is subject to high aerosol loads, especially during spring and summer. A fully coupled regional climate system model (CNRM-RCSM4) including notably atmosphere (ALADIN-Climate) and ocean (NEMO-MED8) has here been used to investigate the aerosol direct and semi-direct effects as well as the perturbation of ocean-atmosphere fluxes by aerosols over this region. Aerosols have been included in the modeling system through realistic interannual monthly AOD climatologies (Nabat et al. 2013). Ensemble simulations have been carried out with and without aerosols and ocean-atmosphere coupling.

First an evaluation of the model has been achieved over land and maritime surfaces, against various observations for meteorological parameters. Some biases have been highlighted, such as a cold bias in winter $2 \mathrm{~m}$-temperature and in summer SST, a positive (negative) bias in SW (LW) radiation, as well as an underestimation of cloud cover. However, our results have shown that the model is able to reproduce the main aspects of the Mediterranean climate, and is comparable to other state of the art RCSMs.

The comparison between C-AER and C-NO simulations has enabled us to identify and characterize the aerosol radiative and climatic effects. Because of the absorption and scattering of the incident solar radiation, the SW surface direct effect is negative, equal on average to $-20.9 \mathrm{Wm}^{-2}$ over the Mediterranean Sea, $-14.7 \mathrm{Wm}^{-2}$ over Europe and $-19.7 \mathrm{Wm}^{-2}$ over northern Africa. The LW surface direct effect is weaker as only dust aerosols contribute $\left(+2.9 \mathrm{Wm}^{-2}\right.$ over northern Africa). This direct 


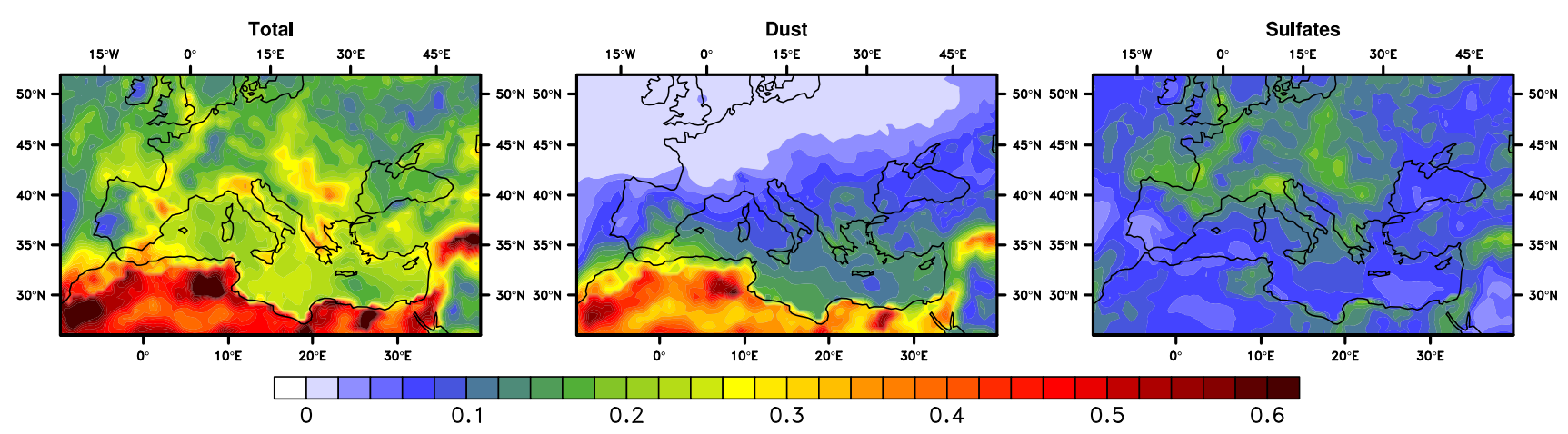

Fig. 15 Aerosol optical depth at $550 \mathrm{~nm}$ for all (left), dust (middle) and sulfate (right) aerosols over the Mediterranean in July 2006

cooling effect is partly counterbalanced by a positive semidirect SW forcing over the Mediterranean Sea $\left(+4.7 \mathrm{Wm}^{-2}\right.$ on average $)$ and Europe $\left(+3.0 \mathrm{Wm}^{-2}\right)$ due to changes in cloud cover and atmospheric circulation. Over Africa, the SW semi-direct effect is however negative $\left(-1.3 \mathrm{Wm}^{-2}\right)$. The net (semi-direct plus direct) aerosol surface effect is consequently negative over Europe, the Mediterranean Sea and northern Africa (respectively $-16.2,-11.7$, and $-21.0 \mathrm{Wm}^{-2}$ ) and is responsible for a decrease in land $\left(-0.4{ }^{\circ} \mathrm{C}\right.$ over Europe and $-0.5{ }^{\circ} \mathrm{C}$ over northern Africa) and sea surface temperature $\left(-0.5^{\circ} \mathrm{C}\right.$ for the Mediterranean Sea).

The coupled system used in this work highlights for the first time the consequences of the decrease of SST due to aerosols on the Mediterranean climate. Such changes in SST are shown to decrease the latent heat loss $\left(-11.0 \mathrm{Wm}^{-2}\right.$ on average over the Mediterranean Sea) resulting in a decrease in specific humidity in the lower troposphere, and a reduction in cloud cover and precipitation. Aerosols tend also to stabilize the atmosphere as particles, especially dust ones, absorb solar radiation in the troposphere (warming), and prevent it from reaching the surface (cooling). All these combined effects have been identified thanks to the ocean-atmosphere coupling. Comparisons with the model response in simulations with prescribed SST show that such feedbacks with ocean cannot occur if SST cannot be modified by aerosol forcing. In addition, a reinforcement of the thermohaline circulation by the aerosols has been identified, because of an increase of sea surface density favouring ocean convection and deep water formation.

Some of these processes have been detailed in two case studies. First, in June 2007, the eastern Mediterranean has been submitted to important dust aerosol loads that reduce land surface temperature and SST. Because of northern wind over the eastern Sea, drier and cooler air has thus been advected from the Mediterranean Sea to the African continent, reinforcing the dust dimming effect. Secondly, in June 2006, an aerosol heat wave hit western Europe due to a powerful ridge extended from Sahara to western Europe causing dry and warm air advection. Coupled simulations indicate that high dust loads present during this month have contributed to reinforcing this ridge and thus to increasing surface and lower atmosphere temperature, illustrating again a positive aerosol-atmosphere-ocean feedback. Aerosols have been identified to explain $0.5{ }^{\circ} \mathrm{C}$ out of the $2.9 \pm 0.1^{\circ} \mathrm{C}$ extra temperature in July 2006 compared to average July (about $15 \%$ ). This last case study underlines a very interesting process where the heating effect due to changes in dynamics (advection of warm air) exceed the cooling effect due to dust dimming. Once more, this dust effect is reinforced in the coupled simulations.

The robustness of these results has been strengthened by the use of 6-member ensembles. However, some uncertainties remain notably in the choice of the aerosol climatology, in the numerical parameterizations of the models, and in the use of RCM. The comparison with the F-NO simulation also raises the problem that prescribed SST used for this simulation has "seen" the radiative effect of aerosols. In future works, aerosol-atmosphere-ocean interactions could be better represented in the CNRMRCSM4 modelling system using an interactive aerosol scheme considering the natural and anthropogenic particles. The 1-day coupling frequency constitutes another limitation of this work as aerosols could modify the diurnal cycle of SST and air-sea fluxes. A finer representation of the first ocean layer in the ocean model is however necessary. Other processes could also be studied, such as for example the feedbacks of the effects of sulfate aerosols in spring, or the aerosol indirect effects which still show large uncertainties (Lohmann and Feichter 2005; Carslaw et al. 2013). In parallel, this coupled modeling system offers some interesting and original possibilities such as the study of aerosol radiative effects on ocean dynamics, notably the effect of particles dimming on the deep water formation. As dust and polluted aerosols can act as nutrients when deposited over the Mediterranean Sea (Guieu et al. 2010), 
(a) - Vertical profiles
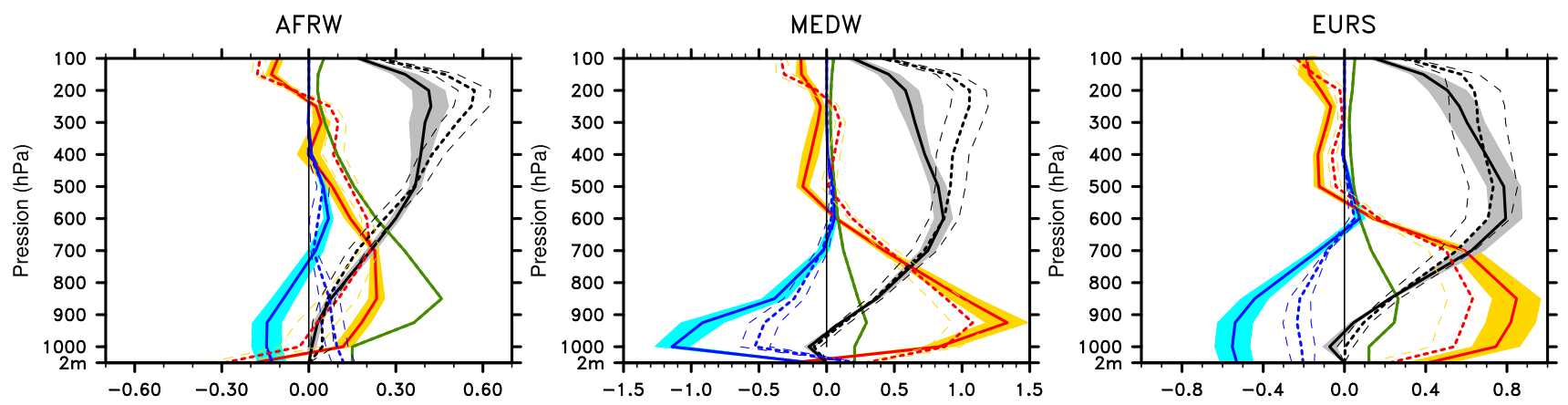

(b) - Atmospheric circulation $(700 \mathrm{hPa})$

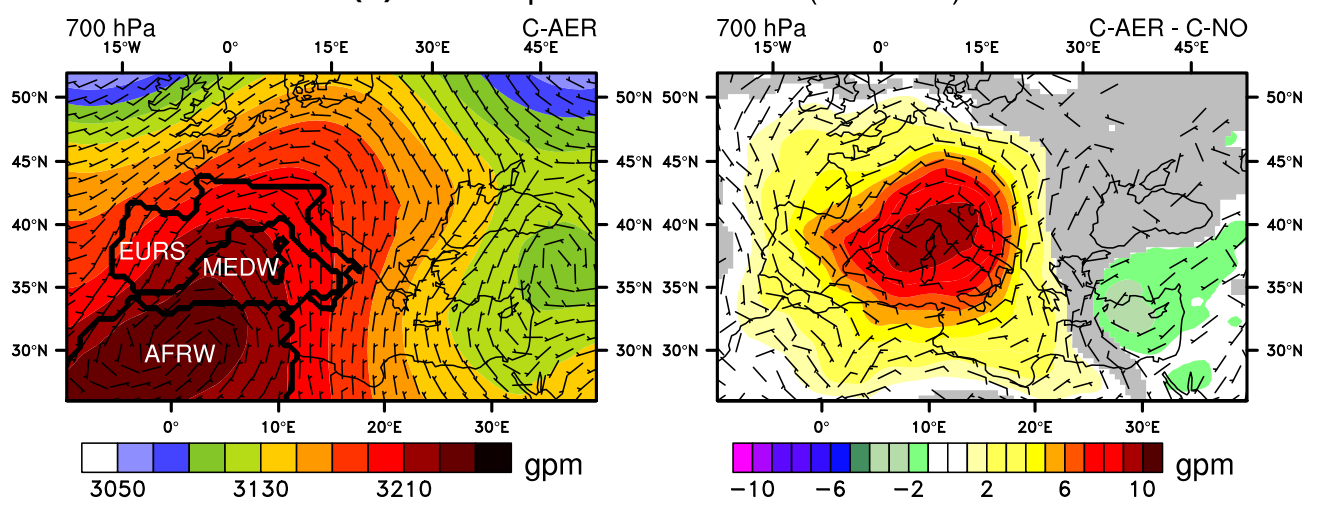

(c) - Temperature

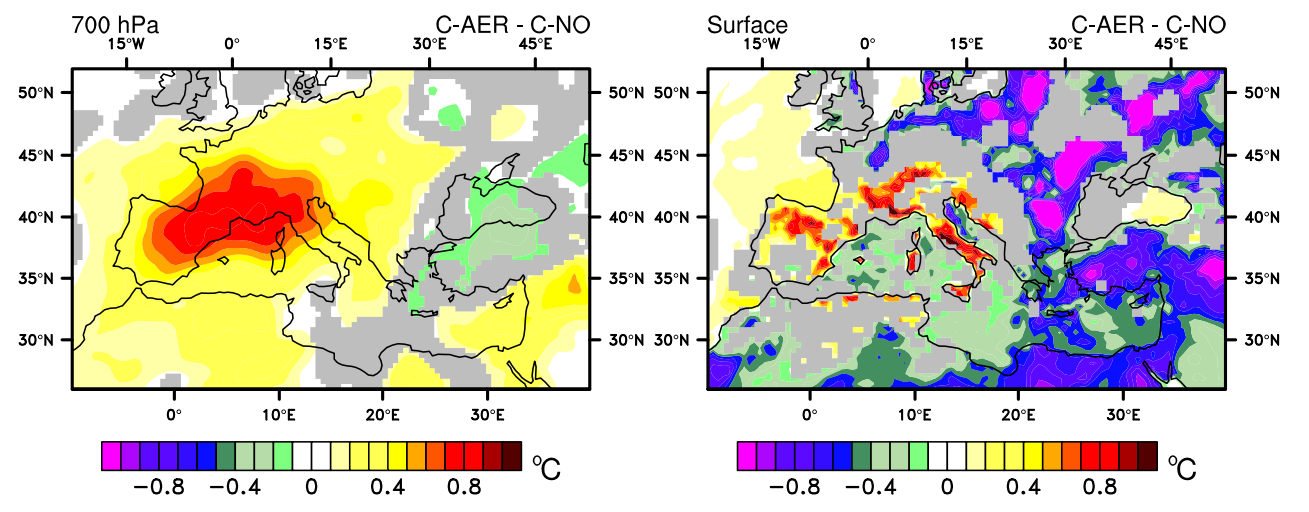

Fig. 16 Vertical profiles (a), atmospheric circulation (b) and aerosol effect on temperature (c) over the Mediterranean in July 2006. Profiles are calculated over Souther Europe (EURS), the western Mediterranean Sea (MEDW) and northwestern Africa (AFRW) using the same legend as Fig. 14a. Atmospheric circulation (b) is represented with geopotential at $700 \mathrm{hPa}$ (gpm, color) and wind barbs (m/

s) at $700 \mathrm{hPa}$ for the C-AER simulation (left), and the difference between C-AER and C-NO (right). The aerosol effect on temperature $\left({ }^{\circ} \mathrm{C}, \mathbf{c}\right)$ is given by the difference between $\mathrm{C}-\mathrm{AER}$ and $\mathrm{C}-\mathrm{NO}$ at 700 $\mathrm{hPa}($ left) and at the surface (right). Only significant values at the level 0.05 are plotted

biogeochemical effects could also be investigated provided a biogeochemistry model is included in the regional coupled system model.

Acknowledgments We would like to thank Meteo-France for the financial support of the first author. This work is part of the MedCORDEX initiative (www.medcordex.eu) and a contribution to the HyMeX and ChArMEx programmes. This research has received funding from the French National Research Agency (ANR) projects ADRIMED (contract ANR-11-BS56-0006) and REMEMBER (contract ANR-12-SENV-0001), as well as from the FP7 European Commission project CLIMRUN (contract FP7-ENV-2010-265192). We would like also to thank all the organizations that provide us with data used in this study, notably the NASA Langley Research Center Atmospheric Science Data Center, the National Center for Atmospheric Research and the European Centre for Medium-Range Weather Forecasts. 
Open Access This article is distributed under the terms of the Creative Commons Attribution License which permits any use, distribution, and reproduction in any medium, provided the original author(s) and the source are credited.

\section{References}

Albrecht BA (1989) Aerosols, cloud microphysics, and fractional cloudiness. Science 245:1227-1230. doi:10.1126/science.245. 4923.1227

Allen RJ, Sherwood SC (2010) Aerosol-cloud semi-direct effect and land-sea temperature contrast in a $\mathrm{gcm}$. Geophys Res Lett 37(L07):702. doi:10.1029/2010GL042759

Artale V, Calmanti S, Carillo A, Dell'Aquila A, Herrmann M, Pisacane G, Ruti PM, Sannino G, Struglia MV, Giorgi F, Bi X, Pal JS, Rauscher S (2010) An atmosphere-ocean regional climate model for the mediterranean area: assessment of a present climate simulation. Clim Dyn 35(5):721-740. doi:10.1007/ s00382-009-0691-8

Balmaseda MA, Mogensen K, Molteni F, Weaver AT (2010) The nemovar-combine ocean re-analysis. Tech. Rep. 1, COMBINE

Bangert M, Kottmeier C, Vogel B, Vogel H (2011) Regional scale effects of the aerosol cloud interaction simulated with an online coupled comprehensive chemistry model. Atmos Chem Phys 11:4411-4423. doi:10.5194/acp-12-4045-2012

Basart S, Pérez C, Cuevas E, Baldasano JM, Gobbi GP (2009) Aerosol characterization in northern africa, northeastern atlantic, mediterranean basin and middle east from direct-sun aeronet observations. Atmos Chem Phys 9:8265-8282

Benas N, Hatzianastassiou N, Matsoukas C, Fotiadi A, Mihalopoulos N, Vardavas I (2011) Aerosol shortwave direct radiative effect and forcing based on modis level 2 data in the eastern mediterranean (crete). Atmos Chem Phys 11:12,647-12,662. doi:10.5194/acp-11-12647-2011

Benedetti A, Kaiser JW, Morcrette JJ (2011) [global climate] aerosols [in "state of the climate in 2010"]. Bull Am Meteorol Soc 92(6):S65-S67

Bergamo A, Tafuro AM, Kinne S, Tomasi FD, Perrone MR (2008) Monthly-averaged anthropogenic aerosol direct radiative forcing over the mediterranean based on aeronet aerosol properties. Atmos Chem Phys 8:6995-7014

Berry DI, Kent EC (2009) A new air-sea interaction gridded dataset from icoads with uncertainty estimates. Bull Am Meteorol Soc 90:645-656. doi:10.1175/2008BAMS2639.1

Beuvier J, Sevault F, Herrmann M, Kontoyiannis H, Ludwig W, Rixen M, Stanev E, Béranger K, Somot S (2010) Modeling the mediterranean sea interannual variability during 1961-2000: focus on the eastern mediterranean transient. J Geophys Res 115(C08):017. doi:10.1029/2009JC005950

Carslaw KS, Lee LA, Reddington CL, Pringle KJ, Rap A, Forster PM, Mann GW, Spracklen DV, Woodhouse MT, Regayre LA, Pierce JR (2013) Large contribution of natural aerosols to uncertainty in indirect forcing. Nature 503:67-79. doi:10.1038/nature12674

Christensen OB, Gaertner MA, Prego JA, Polcher J (2001) Internal variability of regional climate models. Clim Dyn 17:875-887

Coakley JA, Cess RD, Yurevich FB (1983) The effect of tropospheric aerosols on the earths radiation budget: a parameterization for climate models. J Atmos Sci 40:116-138

Colin J, Déqué M, Radu R, Somot S (2010) Sensitivity study of heavy precipitation in limited area model climate simulations: influence of the size of the domain and the use of the spectral nudging technique. Tellus 62A:591-604

Decharme B, Alkama R, Douville H, Becker M, Cazenave A (2010) Global evaluation of the isba-trip continental hydrological system. part ii: Uncertainties in river routing simulation related to flow velocity and groundwater storage. Bull Am Meteorol Soc 11:601-617. doi:10.1175/2010JHM1212.1

Dee DP, Uppala SM, Simmons AJ, Berrisford P, Poli P, Kobayashi S, Andrae U, Balmaseda MA, Balsamo G, Bauer P, Bechtold P, Beljaars ACM, van de Berg L, Bidlot J, Bormann N, Delsol C, Dragani R, Fuentes M, Geer AJ, Haimbergere L, Healy SB, Hersbach H, Hólm EV, Isaksen L, Kallberg P, Köhler M, Matricardi M, McNally AP, Monge-Sanzf BM, Morcrette JJ, Park BK, Peubey C, de Rosnaya P, Tavolato C, Thépaut JN, Vitart F (2011) The era-interim reanalysis: configuration and performance of the data assimilation system. Q J R Meteorol Soc 137:553-597. doi:10.1002/qj.828

Déqué M, Somot S (2008) Extreme precipitation and high resolution with aladin. Idöjaras QJ Hung Meteorol Serv 112(3-4):179-190

Dufresne JL, Gautier C, Ricchiazzi P (2002) Longwave scattering effects of mineral aerosols. J Atmos Sci 59:1959-1966. doi:10. 1175/1520-0469(2002)059<1959:LSEOMA >2.0.CO;2

Ekman AML, Rodhe H (2003) Regional temperature response due to indirect sulfate aerosol forcing: impact of model resolution. Clim Dyn 21:1-10. doi:10.1007/s00382-003-0311-y

Evan AT, Vimont DJ, Heindiger AK, Kossin JP, Bennartz R (2009) The role of aerosols in the evolution of tropical north atlantic ocean temperature anomalies. Science 324:778-781. doi:10. 1126/science. 1167404

Evan AT, Foltz GR, Zhang D, Vimont DJ (2011) Influence of african dust on ocean-atmosphere variability in the tropical atlantic. Nat Geosci 4:762-765. doi:10.1038/NGEO1276

Farda A, Déqué M, Somot S, Horanyi A, Spiridonov V, Toth H (2010) Model aladin as regional climate model for central and eastern europe. Studia Geophysica et Geodaetica 54:313-332. doi:10.1007/s11200-010-0017-7

Formenti P, Boucher O, Reiner T, Sprung D, Andreae MO, Wendisch M, Wex H, Kindred D, Tzortziou M, Vasaras A, Zerefos C (2002) Staaarte-med 1998 summer airborne measurements over the aegean sea 2. Aerosol scattering and absorption, and radiative calculations. J Geophys Res 107:D21. doi:10.1029/2001JD001536

Gao X, Pal JS, Giorgi F (2006) Projected changes in mean and extreme precipitation over the mediterranean region from a high resolution double nested $\mathrm{rcm}$ simulation. Geophys Res Lett 33(L03):706. doi:10.1029/2005GL024954

Geleyn J (1988) Interpolation of wind, temperature and humidity values from model levels to the height of measurement. Tellus 40A:347-351

Gibelin AL, Déqué M (2003) Anthropogenic climate change over the mediterranean region simulated by a global variable resolution model. Clim Dyn 20(4):327-339. doi:10.1007/s00382-002-0277-1

Gilgen H, Ohmura A (1999) The global energy balance archive. Bull Am Meteorol Soc 80:831

Giorgi F, Lionello P (2008) Climate change projections for the mediterranean region. Glob Planet Change 63:90-104. doi:10. 1016/j.gloplacha.2007.09.005

Giorgi F, Bi X, Qian Y (2002) Direct radiative forcing and regional climatic effects of anthropogenic aerosols over east asia: a regional coupled climate-chemistry/aerosol model study. J Geophys Res 107:D20. doi:10.1029/2001JD001066

Giorgi F, Bi X, Qian Y (2003) Indirect vs. direct effects of anthropogenic sulfate on the climate of east asia as simulated with a regional coupled climate-chemistry/aerosol model. Clim Change 58:345-376

Giorgi F, Coppola E, Solmon F, Mariotti L, Sylla MB, Bi X, Elguindi N, Diro GT, Nair V, Giuliani G, Cozzini S, Guettler I, O'Brien TA, Tawfik AB, Shalaby A, Zakey AS, Steiner AL, Stordal F, Sloan LC, Brankovic C (2012) Regcm4: model description and preliminary tests over multiple cordex domains. Clim Res 52:7-29. doi:10.3354/cr01018 
Gkikas A, Houssos E, Hatzianastassiou N, Papadimas C, Bartzokas A (2012) Synoptic conditions favouring the occurrence of aerosol episodes over the broader mediterranean basin. Q J R Meteorol Soc 138:932-949. doi:10.1002/qj.978

Guieu C, Dulac F, Desboeufs K, Wagener T, Pulido-Villena E, Grisoni JM, Louis F, Ridame C, Blain S, Brunet C, Nguyen EB, Tran S, Labiadh M, Dominici JM (2010) Large clean mesocosms and simulated dust deposition: a new methodology to investigate responses of marine oligotrophic ecosystems to atmospheric inputs. Biogeosciences 7:2765-2784. doi:10.5194/bg-7-27652010

Hagemann S, Machenhauer B, Jones R, Christensen OB, Deque M, Jacob D, Vidale PL (2004) Evaluation of water and energy budgets in regional climate models applied over europe. Clim Dyn 23:547-567. doi:10.1007/s00382-004-0444-7

Hansen J, Sato M, Ruedy R (1997) Radiative forcing and climate response. J Geophys Res 102:6831-6864. doi:10.1029/96JD03436

Harris I, Jones P, Osborn T, Lister D (2013) Updated high-resolution grids of monthly climatic observations-the cru ts 3.10 dataset. Int J Climatol 34:623-642. doi:10.1002/joc.3711

Haylock MR, Hofstra N, Tank AMGK, Klok EJ, Jones PD, New M (2008) A european daily high-resolution gridded data set of surface temperature and precipitation. J Geophys Res 113(D20): 119. doi:10.1029/2008JD010201

Herrmann M, Somot S, Calmanti S, Dubois C, Sevault F (2011) Representation of spatial and temporal variability of daily wind speed and of intense wind events over the mediterranean sea using dynamical downscaling: impact of the regional climate model configuration. Nat Hazards Earth Syst Sci 11:1983-2001. doi:10.5194/nhess-11-1983-2011

Hsieh WC, Collins WD, Liu Y, Chiang JCH, Shie CL, Caldeira K, Cao L (2013) Climate response due to carbonaceous aerosols and aerosol-induced sst effects in ncar community atmospheric model cam3.5. Atmos Chem Phys 13:7489-7510. doi:10.5194/ acp-13-7489-2013

IPCC (2007) Climate Change 2007: Synthesis Report. Contribution of Working Groups I, II and III to the Fourth Assessment Report of the Intergovernmental Panel on Climate Change, core writing team, pachauri, r.k and reisinger, a. edn. IPCC, Geneva, Switzerland

Kaufman YJ, Tanré D, Boucher O (2002) A satellite view of aerosolsin the climate system. Nature 419:215-223

Krzic A, Tosic I, Djurdjevic V, Veljovic K, Rajkovic B (2011) Changes in climate indices for serbia according to the sres-a1b and sres-a2 scenarios. Clim Res 49:73-86. doi:10.3354/cr01008

Laprise R (2008) Regional climate modelling. J Comput Phys 227:3641-3666

Lelieveld J, Berresheim H, Borrmann S, Crutzen PJ, Dentener FJ, Fischer H, Feichter J, Flatau PJ, Heland J, Holzinger R, Korrmann R, Lawrence MG, Levin Z, Markowicz KM, Mihalopoulos N, Minikin A, Ramanathan V, de Reus M, Roelofs GJ, Scheeren HA, Sciare J, Schlager H, Schultz M, Siegmund P, Steil B, Stephanou EG, Stier P, Traub M, Warneke C, Williams J, Ziereis H (2002) Global air pollution crossroads over the mediterranean. Science 298:794-799. doi:10.1126/science.1075457

Lionello P, Malanotte-Rizzoli P, Boscolo R, Alpert P, Artale V, Li L, Luterbacher J, May W, Trigo R, Tsimplis M, Ulbrich U, Xoplaki E (2006) The mediterranean climate: an overview of the main characteristics and issues. Dev Earth Environ Sci 4:1-26. doi:10. 1016/S1571-9197(06)80003-0

Loeb NG, Wielicki BA, Doelling DR, Smith GL, Keyes DF, Kato S, Manalo-Smith N, Wong T (2009) Toward optimal closure of the earth's top-of-atmosphere radiation budget. J Clim 22:748-766. doi:10.1175/2008JCLI2637.1

Lohmann U, Feichter J (2005) Global indirect aerosol effects: a review. Atmos Chem Phys 5:715-737. doi:10.5194/acp-5-715-2005
Louis J (1979) A parametric model of vertical eddy fluxes in the atmosphere. Bound-Lay Meteorol 17:187-202

Lucas-Picher P, Caya D, de Elía R, Laprise R (2008) Investigation of regional climate models' internal variability with a ten-member ensemble of 10-year simulations over a large domain. Clim Dyn 31:927-940. doi:10.1007/s00382-008-0384-8

L'Hévéder B, Li L, Sevault F, Somot S (2012) Interannual variability of deep convection in the northwestern mediterranean simulated with a coupled aorcm. Clim Dyn pp 1-24: doi:10.1007/s00382$012-1527-5$

Madec G (2008) Nemo ocean engine. Tech. rep, IPSL

Mallet M, Pont V, Liousse C, Roger JC, Dubuisson P (2006) Simulation of aerosol radiative properties with the orisam-rad model during a pollution event (escompte 2001). Atmos Environ 40:7696-7705. doi:10.1016/j.atmosenv.2006.08.031

Mariotti A, Dell'Aquila A (2012) Decadal climate variability in the mediterranean region: roles of large-scale forcings and regional processes. Clim Dyn 38:1129-1145. doi:10.1007/s00382-0111056-7

Markowicz KM, Flatau PJ, Ramana W, Crutzen PJ, Ramanathan V (2002) Absorbing mediterranean aerosols lead to a large reduction in the solar radiation at the surface. Geophys Res Lett 29:1968. doi:10.1029/2002GL015767

Martinez-Avellaneda N, Serra N, Minnett PJ, Stammer D (2010) Response of the eastern subtropical atlantic sst to saharan dust: a modeling and observational study. J Geophys Res 115(C08):015. doi:10.1029/2009JC005692

Marullo S, Nardelli BB, Guarracino M, Santoleri R (2007) Observing the mediterranean sea from space: 21 years of pathfinder-avhrr sea surface temperatures (1985 to 2005): re-analysis and validation. Ocean sc 3:299-310

Meier J, Tegen I, Heinold B, Wolke R (2012) Direct and semi-direct radiative effects of absorbing aerosols in europe: results from a regional model. Geophys Res Lett 39(L09):802. doi:10.1029/ 2012GL050994

Meloni D, Sarra AD, DeLuisi J, Iorio TD, Fiocco G, Junkermann W, Pace G (2003) Tropospheric aerosols in the mediterranean: 2. Radiative effects through model simulations and measurements. J Geophys Res 108:4317. doi:10.1029/2002JD002807

Meloni D, di Sarra A, Iorio TD, Fiocco G (2004) Direct radiative forcing of saharan dust in the mediterranean from measurements at lampedusa island and misr space-borne observations. J Geophys Res 109(D08):206. doi:10.1029/2003JD003960

Miller RL, Tegen I (1998) Climate response to soil dust aerosols. J Clim 11:3247-3267. doi:10.1175/1520-0442(1998)011<3247: CRTSDA $>2.0 . \mathrm{CO} ; 2$

Mitchell JMJ (1971) The effect of atmospheric aerosols on climate with special reference to temperature near the earth's surface. J Appl Meteorol 10:703-714

Morcrette JJ (1989) Description of the radiation scheme in the ecmwf model. Tech. rep, ECMWF

Moulin C, Lambert CE, Dayan U, Masson V, Ramonet M, Bousquet P, Legrand M, Balkanski YJ, Guelle W, Marticorena B, Bergametti G, Dulac F (1998) Satellite climatology of african dust transport in the mediterranean atmosphere. J Geophys Res 103:13,137-13,144. doi:10.1029/98JD00171

Nabat P, Solmon F, Mallet M, Kok JF, Somot S (2012) Dust emission size distribution impact on aerosol budget and radiative forcing over the mediterranean region: a regional climate model approach. Atmos Chem Phys 12:10,545-10,567. doi:10.5194/ acp-12-10545-2012

Nabat P, Somot S, Mallet M, Chiapello I, Morcrette JJ, Solmon F, Szopa S, Dulac F, Collins W, Ghan S, Horowitz LW, Lamarque JF, Lee YH, Naik V, Nagashima T, Shindell D, Skeie R (2013) A 4-d climatology (1979-2009) of the monthly tropospheric aerosol optical depth distribution over the mediterranean region 
from a comparative evaluation and blending of remote sensing and model products. Atmos Meas Tech 6:1287-1314. doi:10. 5194/amt-6-1287-2013

Noilhan J, Mahfouf JF (1996) The isba land surface parameterisation scheme. Global Planet Change 13:145-159. doi:10.1016/09218181(95)00043-7

Ohmura A, Dutton EG, Forgan B, Fröhlich C, Gilgen H, Hegner H, Heimo A, König-Langlo G, McArthur B, Müller G, Philipona R, Pinker R, Whitlock CH, Dehne K, Wild M (1998) Baseline surface radiation network (bsrn/wcrp): new precision radiometry for climate research. Bull Am Meteorol Soc 79:2115

Oki T, Sud YC (1998) Design of total runoff integrating pathways (trip)-a global river channel network. Earth Interact 2:1-36

Papadimas CD, Hatzianastassiou N, Matsoukas C, Kanakidou M, Mihalopoulos N, Vardavas I (2012) The direct effect of aerosols on solar radiation over the broader mediterranean basin. Atmos Chem Phys 12:7165-7185. doi:10.5194/acp-12-7165-2012

Radu R, Déqué M, Somot S (2008) Spectral nudging in a spectral regional climate model. Tellus 60A:898-910. doi:10.1111/j. 1600-0870.2008.00341.x

Rebetez M, Dupont O, Giroud M (2008) An analysis of the July 2006 heatwave extent in europe compared to the record year of 2003. Theor Appl Climatol 95:1-7. doi:10.1007/s00704-007-0370-9

Rodá F, Bellot J, Avila A, Escarré A, nol JP, Terradas J (1993) Saharan dust and the atmospheric inputs of elements and alkalinity to mediterranean ecosystems. Water Air Soil Pollut 66(3-4):277-288. doi:10.1007/BF00479851

Roger JC, Mallet M, Dubuisson P, Cachier H, Vermote E, Dubovik O, Despiau S (2006) A synergetic approach for estimating the local direct aerosol forcing: application to an urban zone during the expérience sur site pour contraindre les modèles de pollution et de transport d'emission (escompte) experiment. J Geophys Res 111(D13):208. doi:10.1029/2005JD006361

Rosenfeld D, Rudich Y, Lahav R (2001) Desert dust suppressing precipitation: a possible desertification feedback loop. Proc Natl Acad Sci USA 98:5975-5980. doi:10.1073/pnas.101122798

Sanchez-Gomez E, Somot S, Josey SA, Dubois C, Elguindi N, Déqué M (2011) Evaluation of mediterranean sea water and heat budgets simulated by an ensemble of high resolution regional climate models. Clim Dyn 37:2067-2086. doi:10.1007/s00382011-1012-6

Santese M, Perrone MR, Zakey AS, Tomasi FD, Giorgi F (2010) Modeling of saharan dust outbreaks over the mediterranean by regcm3: case studies. Atmos Chem Phys 10:133-156

Schneider U, Fuchs T, Meyer-Christoffer A, Rudolf B (2008) Global precipitation analysis products of the gpcc. Tech. rep., Deutscher Wetterdienst, Offenbach a. M., Germany

Schroeder K, Ribotti A, Borghini M, Sorgente R, Perilli A, Gasparini GP (2008) An extensive western mediterranean deep water renewal between 2004 and 2006. Geophys Res Lett 35(L18):605. doi:10.1029/2008GL035146

Sevault F, Somot S, Alias A, Dubois C, Lebeaupin-Brossier C, Nabat P, Adloff F, Déqué M (2013) A numerical simulation of the 1980-2011 era-interim period for the mediterranean with the regional climate system model cnrm-rcsm4. Tech. Rep. 31, CNRM, Météo France

Somot S, Sevault F, Déqué M (2006) Transient climate change scenario simulation of the mediterranean sea for the twenty-first century using a high-resolution ocean circulation model. Clim Dyn 27:851-879. doi:10.1007/s00382-006-0167-z

Somot S, Sevault F, Déqué M, Crépon M (2008) 21st century climate change scenario for the mediterranean using a coupled atmosphere-ocean regional climate model. Global Planet Change 63:112-126. doi:10.1016/j.gloplacha.2007.10.003

Spyrou C, Kallos G, Mitsakou C, Athanasiadis P, Kalogeri C, Iacono M (2013) Modeling the radiative effects of desert dust on weather and regional climate. Atmos Chem Phys 13:5489-5504. doi:10.5194/acp-13-5489-2013

Stackhouse PW, Gupta SK, Cox SJ, Chiacchio M, Mikovitz C (2000) The wcrp/gewex surface radiation budget project release 2 : an assessment of surface fluxes at 1 degree resolution. In: Smith WL and Timofeyev YM (eds) Symposium international radiation, 2000: current problems in atmospheric radiation. St. Petersburg, Russia

Szczypta C, Decharme B, Carrer D, Calvet JC, Lafont S, Somot S, Faroux S, Martin E (2012) Impact of precipitation and land biophysical variables on the simulated discharge of european and mediterranean rivers. Hydrol Earth Syst Sci 16:3351-3370. doi:10.5194/hess-16-3351-2012

Tegen I, Hollrig P, Chin M, Fung I, Jacob D, Penner J (1997) Contribution of different aerosol species to the global aerosol extinction optical thickness: estimates from model results. J Geophys Res 102:23,895-23,915

Twomey S (1977) The influence of pollution on the shortwave albedo of clouds. J Atmos Sci 34:1149-1152

Valcke S (2013) The oasis3 coupler: a European climate modelling community software. Geosci Model Dev 6:373-388. doi:10. 5194/gmd-6-373-2013

Vogel B, Vogel H, Bümer D, Bangert M, Lundgren K, Rinke R, Stanelle T (2009) The comprehensive model system cosmo-art radiative impact of aerosol on the state of the atmosphere on the regional scale. Atmos Chem Phys 9:8661-8680. doi:10.5194/ acp-9-8661-2009

Voldoire A, Sanchez-Gomez E, y Mélia DS, Decharme B, Cassou C, Sénési S, Valcke S, Beau I, Alias A, Chevallier M, Déqué M, Deshayes J, Douville H, Fernandez E, Madec G, Maisonnave E, Moine MP, Planton S, Saint-Martin D, Szopa S, Tyteca S, Alkama R, Belamari S, Braun A, Coquart L, Chauvin F (2012) The cnrm-cm5.1 global climate model: description and basic evaluation. Clim Dyn 40. doi:10.1007/s00382-011-1259-y

Wild M (2008) Short-wave and long-wave surface radiation budgets in gcms: a review based on the ipcc-ar4/cmip3 models. Tellus 60:932-945. doi:10.1111/j.1600-0870.2008.00342.x

Wild M, Ohmura A, Gilgen H, Roeckner E (1995) Validation of general circulation model radiative fluxes using surface observations. J Clim 8:1309-1324. doi:10.1175/1520-0442

Wild M, Dümenil L, Schulz JP (1996) Regional climate simulation with a high resolution GCM: surface hydrology. Clim Dyn $12: 755-774$

Wild M, Ohmura A, Gilgen H, Morcrette JJ, Slingo A (2001) Evaluation of downward longwave radiation in general circulation models. J Clim 14:3227-3239. doi:10.1175/1520-0442 (2001)014

Wild M, Long CN, Ohmura A (2006) Evaluation of clear-sky solar fluxes in gcms participating in amip and ipcc-ar4 from a surface perspective. J Geophys Res 111(D01):104. doi:10.1029/2005 JD006118

Yu L, Jin X, Weller RA (2008) Multidecade global flux datasets from the objectively analyzed air-sea fluxes (oaflux) project: Latent and sensible heat fluxes, ocean evaporation, and related surface meteorological variables. Tech. rep., Woods Hole Oceanographic Institution OAFlux Project Technical Report (OA-2008-01)

Yue X, Liao H (2012) Climatic responses to the shortwave and longwave direct radiative effects of sea salt aerosol in present day and the last glacial maximum. Clim Dyn 39:3019-3040. doi:10.1007/s00382-012-1312-5

Yue X, Liao H, Wang HJ, Li SL, Tang JP (2011) Role of sea surface temperature responses in simulation of the climatic effect of mineral dust aerosol. Atmos Chem Phys 11:6049-6062. doi:10. 5194/acp-11-6049-2011

Zanis P (2009) A study on the direct effect of anthropogenic aerosols on near surface air temperature over southeastern europe during 
summer 2000 based on regional climate modeling. Annales Geophysicae 27:3977-3988

Zanis P, Ntogras C, Zakey A, Pytharoulis I, Karacostas T (2012) Regional climate feedback of anthropogenic aerosols over europe using regcm3. Clim Res 52:267-278. doi:10.3354/cr01070

Zhang YC, Rossow WB, Lacis AA, Oinas V, Mishchenko MI (2004) Calculation of radiative fluxes from the surface to top of atmosphere based on iscep and other global data sets:
Refinements of the radiative transfer model and the input data. J Geophys Res 109:D19. doi:10.1029/2003JD004457

Zubler EM, Folini D, Lohmann U, Lüthi D, Schär C, Wild M (2011) Simulation of dimming and brightening in europe from 1958 to 2001 using a regional climate model. J Geophys Res 116(D18): 205. doi:10.1029/2010JD015396 